\title{
A Review of PV Inverter Technology Cost and Performance Projections
}

Subcontract Report NREL/SR-620-38771 January 2006

Navigant Consulting Inc.

Burlington, Massachusetts

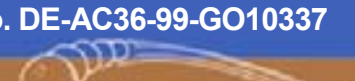




\section{A Review of PV Inverter Technology Cost and Performance Projections}

Navigant Consulting Inc.

Burlington, Massachusetts

NREL Technical Monitor: R. Margolis

Prepared under Subcontract No. KACX-4-44451-01 


\section{NOTICE}

This report was prepared as an account of work sponsored by an agency of the United States government. Neither the United States government nor any agency thereof, nor any of their employees, makes any warranty, express or implied, or assumes any legal liability or responsibility for the accuracy, completeness, or usefulness of any information, apparatus, product, or process disclosed, or represents that its use would not infringe privately owned rights. Reference herein to any specific commercial product, process, or service by trade name, trademark, manufacturer, or otherwise does not necessarily constitute or imply its endorsement, recommendation, or favoring by the United States government or any agency thereof. The views and opinions of authors expressed herein do not necessarily state or reflect those of the United States government or any agency thereof.

Available electronically at http://www.osti.gov/bridge

Available for a processing fee to U.S. Department of Energy and its contractors, in paper, from:

U.S. Department of Energy

Office of Scientific and Technical Information

P.O. Box 62

Oak Ridge, TN 37831-0062

phone: 865.576 .8401

fax: 865.576 .5728

email: mailto:reports@adonis.osti.gov

Available for sale to the public, in paper, from:

U.S. Department of Commerce

National Technical Information Service

5285 Port Royal Road

Springfield, VA 22161

phone: 800.553 .6847

fax: 703.605.6900

email: orders@ntis.fedworld.gov

online ordering: http://www.ntis.gov/ordering.htm 


\section{A Review of PV Inverter \\ Technology Cost and Performance Projections}

Final Presentation Report to

National Renewable Energy Laboratory

This work was supported by the U.S. Department of Energy's (U.S. DOE) Office of Energy Efficiency and Renewable Energy (EERE) under National Renewable Energy Laboratory (NREL)

Contract No. KACX-4-44451-04 
1 Executive Summary

2 Introduction

$3 \quad$ Historical Perspective

4 Future Performance and Cost Estimates

5 Challenges for Achieving Future Targets

6 Addressing the Challenges

7 Suggested Role for Government 
1 Executive Summary

2 Introduction

3 Historical Perspective

44 Future Performance and Cost Estimates

5 Challenges for Achieving Future Targets

6 Addressing the Challenges

7 Suggested Role for Government 


\section{Executive Summary Study Objective}

\section{Navigant Consulting Inc. (NCI) evaluated PV inverter technology and cost improvements required to meet U.S. DOE goals for 2020.}

- The National Renewable Energy Laboratory (NREL) has a major responsibility in the implementation of the U.S. Department of Energy's (DOE's) Solar Energy Technologies Program. Sandia National Laboratories (SNL) has a major role in supporting inverter development, characterization, standards, certifications, and verifications.

- The Solar Energy Technologies Program recently published a Multiyear Technical Plan, which establishes a goal of reducing the Levelized Energy Cost (LEC) for photovoltaic (PV) systems to $\$ 0.06 / \mathrm{kWh}$ by 2020 .

- The Multiyear Technical Plan estimates that, in order to meet the PV system goal, PV inverter prices will need to decline to \$0.25-0.30 Wp by 2020.

- DOE determined the need to conduct a rigorous review of the PV Program's technical and economic targets, including the target set for PV inverters.

- NREL requested that NCI conduct a review of historical and projected cost and performance improvements for PV inverters, including identification of critical barriers identified and the approaches government might use to address them. 
NREL's questions regarding PV inverter cost and performance, and the role they should play, were broken down into three key questions.

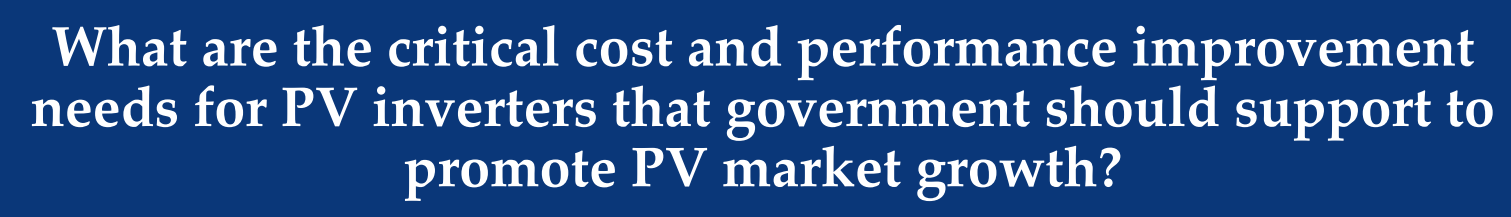

What are the critical cost and performance improvement needs for PV inverters that government should support to promote PV market growth?

Do PV inverters face challenges in meeting the U.S. DOE's Solar Energy Technologies Program targets?*

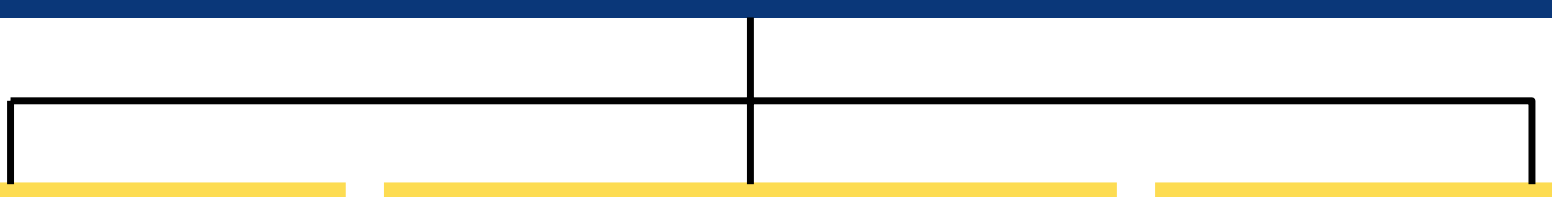

Is there a clear understanding and consensus for addressing key PV inverter challenges?
What role should government play in addressing the key challenges that PV inverters face?

* This includes the question: “Will inverters reach the cost goal set by the Solar Energy Technologies Program?" 


\section{Many potential roles for government were identified that can help to improve the chances that DOE program targets are achieved.}

\section{What are the critical cost and performance improvement needs for PV inverters that government should support to promote PV market growth?}

\begin{tabular}{|c|c|c|}
\hline $\begin{array}{c}\text { Do PV inverters face } \\
\text { challenges in meeting DOE's } \\
\text { Solar Energy Technologies } \\
\text { Program targets?* }\end{array}$ & $\begin{array}{l}\text { Is there a clear understanding } \\
\text { and consensus for addressing } \\
\text { key PV inverter challenges? }\end{array}$ & $\begin{array}{c}\text { What role should government } \\
\text { play in addressing the key } \\
\text { challenges that PV inverters } \\
\text { face? }\end{array}$ \\
\hline $\begin{array}{l}\text { - Sales-volume increases and } \\
\text { learning-curve improvements } \\
\text { alone appear unlikely to achieve } \\
\text { the targeted inverter selling price } \\
\text { of } \$ 0.25-0.30 / W \text { by } 2020 \text {. } \\
\text { - Inverter lifetimes greater than } 15 \\
\text { years appear difficult to achieve. } \\
\text { - Improvements in manufacturing, } \\
\text { design, and technology are } \\
\text { needed to achieve the price and } \\
\text { performance targets. } \\
\text { - Reducing regulatory complexity } \\
\text { and long-term, consistent policy } \\
\text { will also be required. }\end{array}$ & $\begin{array}{l}\text { - Manufacturers and industry } \\
\text { experts do not agree on needs to } \\
\text { address key inverter challenges. } \\
\text { - Support is needed in several } \\
\text { areas: } \\
\text { - Manufacturing and testing } \\
\text { improvements: process } \\
\text { improvement, training, quality } \\
\text { management, HALT/HASS } \\
\text { assistance, and documenting field } \\
\text { performance data. } \\
\text { - Design: alternative topologies, } \\
\text { thermal management, modeling, } \\
\text { and DER inverters. } \\
\text { - Technology: advanced switching, } \\
\text { capacitors, and components. }\end{array}$ & $\begin{array}{l}\text { Assistance with testing } \\
\text { methodologies for inverter } \\
\text { ratings. Access to training in } \\
\text { manufacturing processes and } \\
\text { quality control. Support to } \\
\text { understand field performance } \\
\text { and failure data. } \\
\text { - Support for public-private } \\
\text { partnerships for R\&D on new } \\
\text { technologies, topologies, and } \\
\text { modeling. } \\
\text { - Information and analysis to support: } \\
\text { - Evaluation of regulatory and } \\
\text { safety requirements. } \\
\text { - Evaluation of alternative policy } \\
\text { approaches. }\end{array}$ \\
\hline
\end{tabular}




\section{Executive Summary Future Performance}

\section{Achieving the targeted improvements of lower cost and higher reliability for inverters is not a foregone conclusion for the industry.}

- Based on learning-curve forecasts, the targeted cost reductions for 2020 will not be achieved with current market growth and learning-rate levels.

- Significant uncertainty exists around the potential for future market growth to exceed current levels for an extended period of time.

- Additional cost reductions will require an acceleration of learning effects.

$>$ Inverter prices have been dropping by about $10 \%$ with every doubling of cumulative production, compared to $20 \%$ for PV modules.

- Reliability and life issues for inverters have the potential to damage the reputation of the industry and long-term adoption of PV.

- Because of market demands, manufacturers today are focused on lowering first cost over improving reliability.

- Reliability and life improvements may not be achieved with consistency across the industry.

In order to increase the probability of achieving the goals of industry, which are necessary for the PV market to become sustainable over the long term, ongoing government support for inverter R\&D is likely to be necessary. 


\section{Executive Summary Overcoming Key Challenges}

\section{NCI's assessment is that there is an important role for government to support PV inverter improvements for the next several years.}

- In general, larger companies in the PV inverter business view the role of government in providing assistance (via programs to reduce cost and increase reliability) as being less critical to their success and the long-term future of the industry.

- Most larger companies that NCI spoke to believe that increasing sales volume is the single largest factor that will lead to lower cost and higher reliability for PV inverters.

- Despite the views of larger companies, introducing a new inverter product has proven to be a risky venture for some large companies. For example:

- Xantrex experienced significant problems with their early PV inverters and ended up losing market share to new European market entrants.

- Philips entered the PV inverter market in Europe, only to exit a few years later after experiencing significant technical problems with their first product.

- The PV market will be in a critical growth phase during the next 5-10 years, continuing to require significant policy and market support to achieve the overall cost and performance required for a sustainable market.

- If small manufacturers have more difficulty meeting the reliability requirements of the market and cannot afford to provide adequate after-sales service, it could hurt the PV industry as a whole (inadequately performing inverters will hurt the industry).

- While some consolidation in the inverter business should be expected, the benefits of competition and innovation provided by the smaller companies are likely to be important to the industry at its current, early stage of development. 


\section{Executive Summary Suggested Role for Government}

\section{Long-term cost reduction and performance improvements will benefit greatly from the ongoing support of additional government programs.}

- Inverter testing at Sandia National Labs is extremely valuable to the industry, and continued support of development of testing protocols is important to the industry.

- Documentation of failure analysis in the industry is not conducted uniformly. A possible role for government would be in collecting and documenting inverter failures to share with the industry.

- Modeling tools would be helpful to manufacturers, but developing accurate models is challenging. An assessment of issues and needs related to modeling would be appropriate before embarking on new modeling efforts.

- The High Reliability Inverter Initiative (HRII) program is generally considered to have been successful. Follow-on public-private R\&D partnerships such as this should continue to receive government support.

- Cost and efficiency benefits of tranformerless inverters are understood. Studies on the pros and cons of tranformerless inverters as a means of educating inspectors and regulators would be beneficial to encourage adoption of regulations and codes that allow their use.

- Analysis of the interaction of the various federal, state, and municipal support programs will be increasingly important to future industry growth needed for long-term success. 


\section{Executive Summary Suggested Role for Government}

\section{Several issues identified are common to all DER inverters and could be addressed as part of crosscutting research programs.}

- Comprehensive information on inverter components (capacitors, electrical connectors, power semiconductors, etc.) and options would assist manufacturers in identifying the best products.

- Innovative inverter topologies have been suggested to provide many benefits. A role for government may be in support of experimental topologies as a means of advancing the industry.

- Manufacturers would benefit from understanding the costs and benefits of the Highly Accelerated Life Testing (HALT) and Highly Accelerated Stress Screening (HASS) testing programs. Government could assist by providing general guidelines and experience from other industries.

- Several other areas identified for PV inverters may also have broader benefit to DER inverters, such as modeling and specific HALT and HASS testing protocols; but more programs targeted specifically for PV are likely to be required. 


\begin{tabular}{|c|l|}
\hline 1 & Executive Summary \\
\hline 2 & Introduction \\
\hline 3 & Historical Perspective \\
\hline 4 & Future Performance and Cost Estimates \\
\hline 5 & Challenges for Achieving Future Targets \\
\hline 6 & Addressing the Challenges \\
\hline 7 & Suggested Role for Government \\
\hline
\end{tabular}




\section{Navigant Consulting Inc. (NCI) evaluated the PV inverter technology and cost improvements required to meet U.S. DOE goals for 2020.}

- The National Renewable Energy Laboratory (NREL) has a major responsibility in the implementation of the U.S. Department of Energy's (DOE's) Solar Energy Technologies Program. Sandia National Laboratories (SNL) has a major role in supporting inverter development, characterization, standards, certifications, and verifications .

- The Solar Energy Technologies Program recently published a Multiyear Technical Plan, which establishes a goal of reducing the Levelized Energy Cost (LEC) for photovoltaic (PV) systems to $\$ 0.06 / \mathrm{kWh}$ by 2020 .

- The Multiyear Technical Plan estimates that, in order to meet the PV system goal, PV inverter prices will need to decline to $\$ 0.25-0.30 \mathrm{Wp}$ by 2020.

- DOE determined the need to conduct a rigorous review of the PV Program's technical and economic targets, including the target set for PV inverters.

- NREL requested that NCI conduct a review of historical and projected cost and performance improvements for PV inverters, including identification of critical barriers identified and the approaches government might use to address them. 
NREL's key questions regarding PV inverter cost and performance, and the role they should play, can be broken down into three key questions.

\section{What are the critical cost and performance improvement needs for PV inverters that government should support to promote PV market growth?}

Do PV inverters face challenges in meeting the U.S. DOE's Solar Energy Technologies Program targets?*

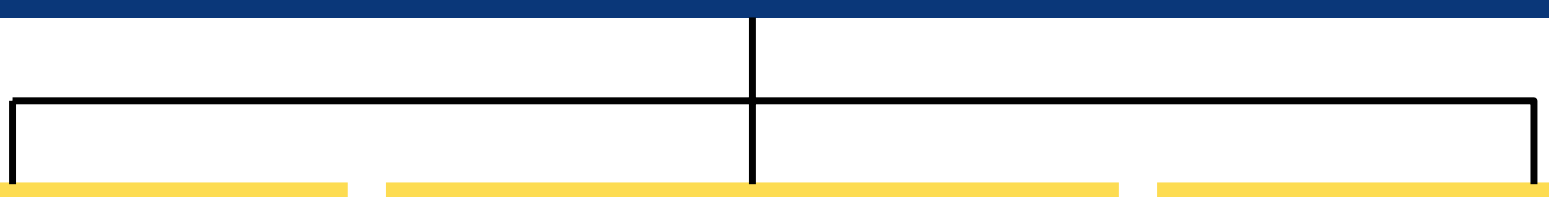

Is there a clear understanding and consensus for addressing key PV inverter challenges?
What role should government play in addressing the key challenges that PV inverters face?

\footnotetext{
* This includes the question: “Will inverters reach cost goal set by the Solar Energy Technologies Program?"
} 


\section{NCI's five-step project approach provided the basis for addressing NREL's questions.}
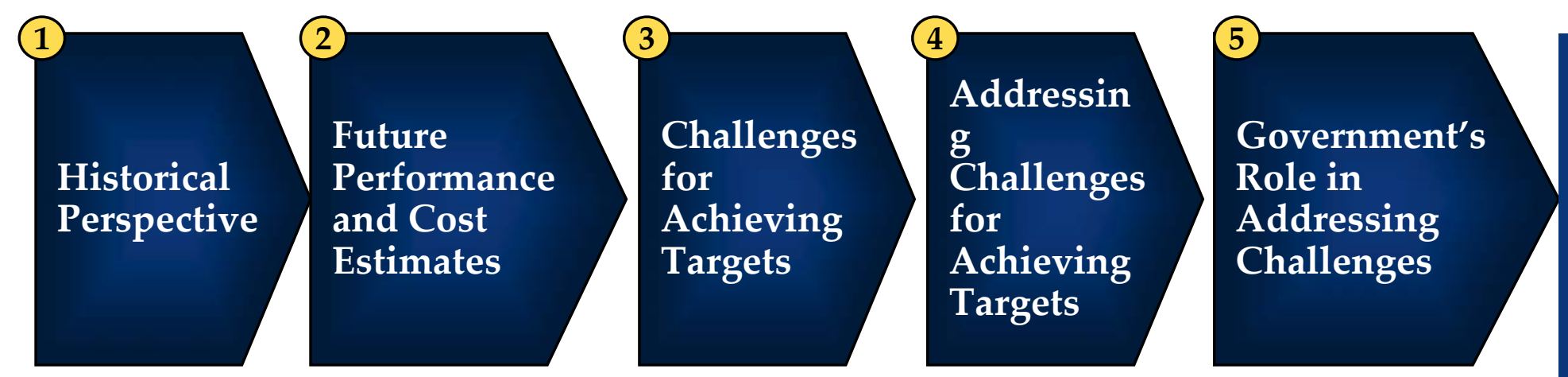

Do PV inverters face challenges in meeting the U.S. DOE's Solar Energy Technologies Program's targets?

Is there a clear understanding and consensus for addressing key PV inverter challenges?

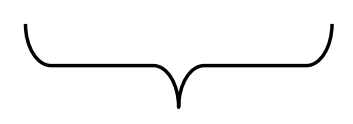

What role should the U.S. DOE play in addressing the key challenges that PV inverters face? 


\section{NCI first collected data on inverter trends for the past 8 years.}

\begin{tabular}{|l|}
\hline Historical Perspect \\
\hline \multicolumn{1}{|c|}{ Objective } \\
\hline $\begin{array}{l}\text { Provide } \\
\text { performance and } \\
\text { cost information } \\
\text { on typical } \\
\text { inverters used for } \\
\text { U.S. residential } \\
\text { and commercial } \\
\text { buildings, and } \\
\text { central } \\
\text { power/utility } \\
\text { applications. }\end{array}$ \\
\hline
\end{tabular}

\section{Tasks}

- Pricing information and key performance information for inverters during the past 3-5 years.

- Key information about product attributes, such as weight, voltage range, and sizes of commercial and residential units.

- Advantages and limitations of past products.

\begin{tabular}{|c|}
\hline Approach \\
\hline - Obtain product information \\
from company Web sites. \\
- Call the top players (e.g. SMA, \\
Xantrex, Fronius) to discuss past \\
performance and cost issues. \\
- Interview key inverter and \\
module manufacturers at \\
European PV conference in \\
Barcelona to obtain their views \\
as well as possible reports or \\
other documentation for review. \\
\hline
\end{tabular}




\section{NCI conducted interviews with inverter players in Europe and the United States to identify likely cost and performance trends for the next 10 years.}

\begin{tabular}{|l|}
\hline Future Performan \\
Cost Estimates \\
\hline \multicolumn{1}{|c|}{ Objective } \\
\hline $\begin{array}{l}\text { Provide } \\
\text { information on } \\
\text { inverter cost and } \\
\text { performance } \\
\text { trends that are } \\
\text { expected during } \\
\text { the next } 10-20 \\
\text { years. }\end{array}$ \\
\hline
\end{tabular}

\section{Tasks}

- Show how inverter prices are likely to change during the next 10-20 years.

(Include assumptions about market size driving economies of scale and learning)

- Discuss likely customer inverter needs for residential, commercial, and central inverter applications.

- Show likely changes in inverter performance during the next 10-20 years.

\begin{tabular}{|l|}
\hline \multicolumn{1}{|c|}{ Approach } \\
\hline -Update in-house knowledge \\
base. \\
- Call the top players (e.g. \\
SMA, Xantrex, Fronius) to \\
discuss past performance \\
and cost issues. \\
- Interview key inverter and \\
module manufacturers at \\
European PV conference in \\
Barcelona to obtain their \\
views as well as possible \\
reports or other \\
documentation for review. \\
\hline
\end{tabular}




\section{Introduction Step 3-Challenges for Achieving Targets}

\section{The interviews provided information on some of the challenges for achieving the cost and performance targets.}

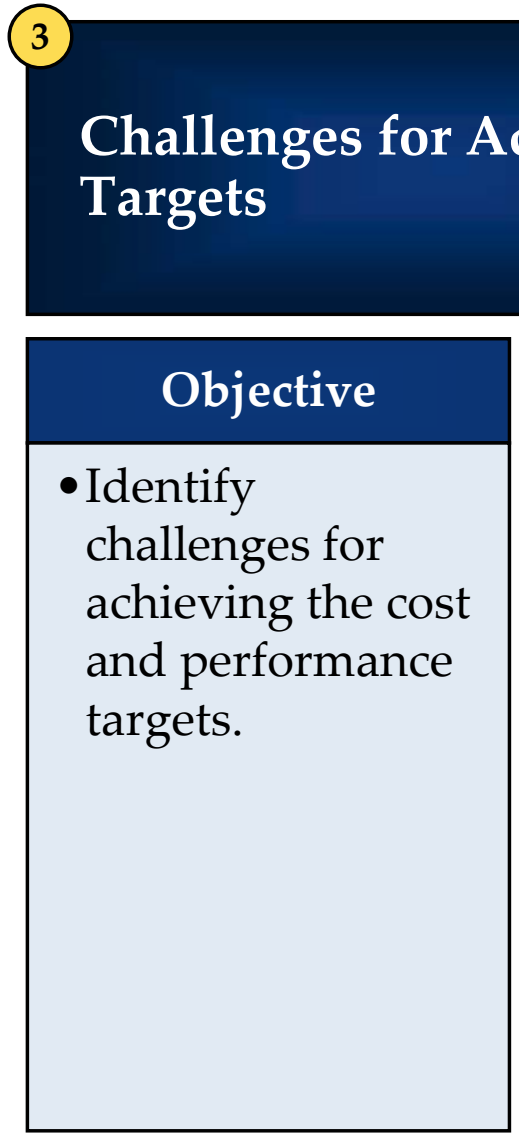

\section{Tasks}

- Discuss potential barriers for cost and performance targets for residential, commercial, and central station applications.

- Discuss technical, manufacturing, regulatory, policy, and market challenges.

\section{Approach}

- Review literature

- Interview select inverter manufacturers in the $R \& D$, marketing, and sales divisions.

- Interview staff at research organizations in the United States, such as SNL; and, in Europe, such as the Fraunhofer Institute. 


\section{Introduction Step 4-Addressing Challenges}

\section{NCI then identified possible ways to address the challenges for achieving the cost and performance targets.}

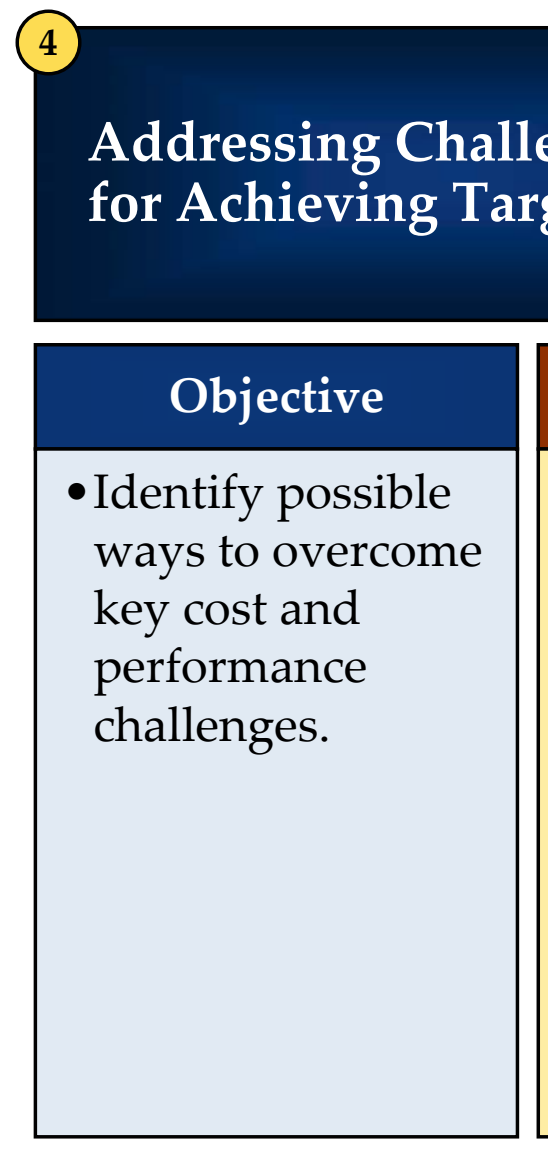

\section{Tasks}

- Identify possible ways to address inverter challenges during the next 10 years that can help industry achieve its cost and performance targets.

\section{Approach}

- Conduct select interviews with R\&D or engineering staff of select inverter manufacturers.

- Summarize interview findings. 


\section{Introduction Step 5 - Role for U.S. DOE}

\section{NCI then identified activities the U.S. DOE could support to address PV inverter challenges in achieving cost and performance targets.}

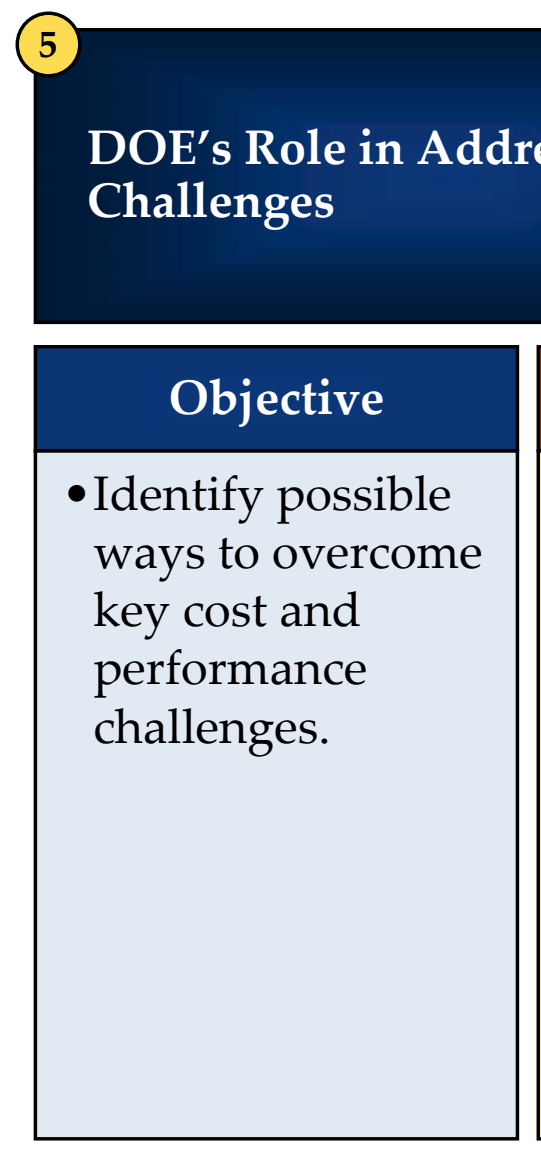

\section{Tasks}

- Identify possible ways to address inverter challenges during the next 10 years that can help industry achieve its cost and performance targets.

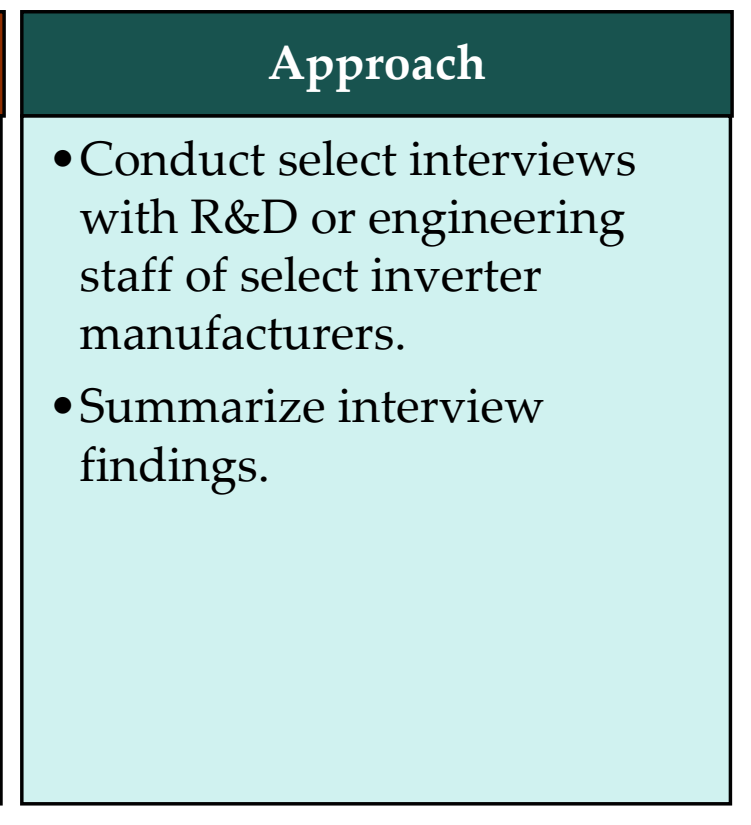




\begin{tabular}{|c|l|}
\hline 1 & Executive Summary \\
\hline 2 & Introduction \\
\hline 3 & Historical Perspective \\
\hline 4 & Future Performance and Cost Estimates \\
\hline 5 & Challenges for Achieving Future Targets \\
\hline 6 & Addressing the Challenges \\
\hline 7 & Suggested Role for Government \\
\hline
\end{tabular}




\section{The U.S. grid-connected market has been strongest in California where buy-down programs make systems more economically attractive.}

U.S. Market

- There has not been a national subsidy program for PV, only a $10 \%$ federal investment tax credit on commercial applications and a 5-year accelerated depreciation, so support has been dependent largely on state programs.

- The recently passed Energy Bill includes \$400 million worth of solar incentives (PV and solar thermal), including a 30\% investment tax credit for both residential homeowners and commercial building owners for the next 2 years. The residential credit is capped at $\$ 2,000$ per credit.

- NCI estimates the U.S. grid-connected market to be $51 \mathrm{MW}$ in 2004. California is the largest market with $37 \mathrm{MW}$ installed in 2004, resulting in a cumulative market of about 93 MW for grid-connected systems at the end of 2004.

- The most common installation size for residential systems in California is 4-5 kW. Installations of greater than $10 \mathrm{~kW}$ are becoming more common. The California Energy Commission (CEC) is considering a feed-in tariff (utility buyback rate) for PV.

- In the United States, where grid reliability has been a problem in recent years, the demand for grid-connected inverters that can also provide backup power from batteries is higher than in Europe. 
Historical Perspective U.S. PV Market » Installation Sizes

\section{CEC data shows the proportion of installations of $3 \mathrm{~kW}$ or less is declining, while $10-30 \mathrm{~kW}$ installations are on the rise.}

\begin{tabular}{|c|c|c|c|c|c|c|c|c|}
\hline \multicolumn{9}{|c|}{ Installation Size Distribution in CEC Program (kW installed) } \\
\hline \multicolumn{9}{|c|}{ Residential and Small Commercial $(<30 \mathrm{~kW})$} \\
\hline kW & \multicolumn{2}{|c|}{2001} & \multicolumn{2}{|c|}{2002} & \multicolumn{2}{|c|}{2003} & \multicolumn{2}{|c|}{2004} \\
\hline $0-<2.0$ & 419.3 & $15.1 \%$ & 798.6 & $11.1 \%$ & 779.8 & $6.5 \%$ & 532.4 & $4.3 \%$ \\
\hline $2.0-<3.0$ & 885.6 & $32.0 \%$ & $1,777.1$ & $24.7 \%$ & $2,595.0$ & $21.8 \%$ & $2,324.6$ & $18.7 \%$ \\
\hline $3.0-<5.0$ & 824.7 & $29.8 \%$ & $1,964.2$ & $27.3 \%$ & $3,214.8$ & $27.0 \%$ & $3,544.6$ & $28.5 \%$ \\
\hline $5.0-<10.0$ & 605.0 & $21.8 \%$ & $2,328.7$ & $32.3 \%$ & $4,070.0$ & $34.2 \%$ & $4,193.7$ & $33.8 \%$ \\
\hline $10.0-<30.0$ & 36.4 & $1.3 \%$ & 332.8 & $4.6 \%$ & $1,256.2$ & $10.5 \%$ & $1,821.3$ & $14.7 \%$ \\
\hline TOTAL & $2,771.0$ & $100.0 \%$ & $7,201.4$ & $100.0 \%$ & $11,915.8$ & $100.0 \%$ & $12,416.5$ & $100.0 \%$ \\
\hline \multicolumn{9}{|c|}{ Residential and Small Commercial $(<30 \mathrm{~kW})$ vs. Large Systems } \\
\hline$<30$ & $2,771.0$ & $83.5 \%$ & $7,201.4$ & $89.4 \%$ & $11,915.8$ & $92.5 \%$ & $12,416.5$ & $100.0 \%$ \\
\hline $30+$ & 548.9 & $16.5 \%$ & 857.2 & $10.6 \%$ & 962.2 & $7.5 \%$ & 0.0 & $0.0 \%$ \\
\hline TOTAL & $3,319.9$ & $100.0 \%$ & $8,058.6$ & $100.0 \%$ & $12,878.0$ & $100.0 \%$ & $12,416.5$ & $100.0 \%$ \\
\hline
\end{tabular}

Installation size refers to the size of the PV system, not the size of the individual inverters.

$\mathrm{kW}$ shown are for systems installed within the CEC program only. 
Historical Perspective U.S. PV Market » Installation Sizes

Compared to CEC, data for New Jersey residential and commercial PV installations shows an even stronger trend toward larger installations.

\begin{tabular}{|l|c|c|c|c|c|c|c|c|}
\hline \multicolumn{7}{|c|}{ Installation Size Distribution in NJ (kW installed) } \\
\hline \multicolumn{1}{|c|}{ kW } & \multicolumn{2}{|c|}{$\mathbf{2 0 0 1}$} & \multicolumn{2}{|c|}{$\mathbf{2 0 0 2}$} & \multicolumn{2}{c|}{$\mathbf{2 0 0 3}$} & \multicolumn{2}{c|}{$\mathbf{2 0 0 4}$} \\
\hline $\mathbf{0}-<\mathbf{2 . 0}$ & 1.5 & $20.0 \%$ & 7.4 & $5.5 \%$ & 1.4 & $0.1 \%$ & 4.0 & $0.3 \%$ \\
\hline $\mathbf{2 . 0}-<\mathbf{3 . 0}$ & 2.3 & $30.7 \%$ & 32.3 & $24.2 \%$ & 41.9 & $3.4 \%$ & 14.0 & $1.0 \%$ \\
\hline $\mathbf{3 . 0}-<\mathbf{5 . 0}$ & 3.8 & $50.7 \%$ & 17.4 & $13.0 \%$ & 271.9 & $21.9 \%$ & 176.0 & $12.5 \%$ \\
\hline $\mathbf{5 . 0}-<\mathbf{1 0 . 0}$ & 0.0 & $0.0 \%$ & 25.8 & $19.3 \%$ & 531.7 & $42.9 \%$ & 651.0 & $46.4 \%$ \\
\hline $\mathbf{1 0 . 0}-<\mathbf{3 0 . 0}$ & 0.0 & $0.0 \%$ & 50.5 & $37.9 \%$ & 392.0 & $31.6 \%$ & 559.0 & $39.8 \%$ \\
\hline TOTAL & 7.5 & $100.0 \%$ & 133.4 & $100.0 \%$ & $1,238.9$ & $100.0 \%$ & $1,404.0$ & $100.0 \%$ \\
\hline \hline \multicolumn{7}{|c|}{ Residential and Small Commercial (<30 kW) vs. Large Systems } \\
\hline $\mathbf{3 0}$ & 7.5 & $100.0 \%$ & 133.4 & $21.6 \%$ & $1,238.9$ & $18.3 \%$ & $1,404.0$ & $9.1 \%$ \\
\hline $\mathbf{3 0}+$ & 0.0 & $0.0 \%$ & 485.0 & $78.4 \%$ & $5,514.8$ & $81.7 \%$ & $14,048.0$ & $90.9 \%$ \\
\hline TOTAL & 7.5 & $100.0 \%$ & 618.4 & $100.0 \%$ & $6,753.7$ & $100.0 \%$ & $15,452.0$ & $100.0 \%$ \\
\hline
\end{tabular}


Historical Perspective U.S. PV Market » Inverter Sizes

CEC data shows that inverters in the $2-3 \mathrm{~kW}$ range dominate the market (SMA SB 2500). Sharp's Sunvista 3500 accounts for the recent growth in the 3-5 $\mathrm{kW}$ range.

\begin{tabular}{|l|c|c|c|c|c|c|c|c|}
\hline \multirow{2}{*}{$\begin{array}{c}\text { Size of } \\
\text { inverter(s) } \\
\text { used (kW) }\end{array}$} & \multicolumn{7}{c|}{ Inverter Size Distribution in CEC Program } \\
\cline { 2 - 10 } & $\mathbf{2 0 0 1}$ & \multicolumn{2}{|c|}{$\mathbf{2 0 0 2}$} & \multicolumn{2}{c|}{$\mathbf{2 0 0 3}$} & \multicolumn{2}{c|}{$\mathbf{2 0 0 4}$} \\
\hline $\mathbf{0}-<\mathbf{2 . 0}$ & 183.9 & $5.5 \%$ & 429.8 & $5.3 \%$ & 658.8 & $5.1 \%$ & 566.5 & $4.6 \%$ \\
\hline $\mathbf{2 . 0}-<\mathbf{3 . 0}$ & $1,243.7$ & $37.5 \%$ & $5,466.2$ & $67.8 \%$ & $9,905.0$ & $76.9 \%$ & $9,565.8$ & $77.0 \%$ \\
\hline $\mathbf{3 . 0}-<\mathbf{5 . 0}$ & 20.0 & $0.6 \%$ & 339.8 & $4.2 \%$ & 173.0 & $1.3 \%$ & $1,216.1$ & $9.8 \%$ \\
\hline $\mathbf{5 . 0}-<\mathbf{1 0 . 0}$ & 8.8 & $0.3 \%$ & 509.4 & $6.3 \%$ & 430.2 & $3.3 \%$ & 205.3 & $1.7 \%$ \\
\hline $\mathbf{1 0 . 0}-<\mathbf{3 0 . 0}$ & 73.6 & $2.2 \%$ & 520.9 & $6.5 \%$ & 668.5 & $5.2 \%$ & 306.0 & $2.5 \%$ \\
\hline $\mathbf{3 0 . 0}+$ & 0.0 & $0.0 \%$ & 192.8 & $2.4 \%$ & 760.5 & $5.9 \%$ & 114.3 & $0.9 \%$ \\
\hline $\begin{array}{l}\text { Inverter size } \\
\text { not reported }\end{array}$ & $1,790.0$ & $53.9 \%$ & 599.7 & $7.4 \%$ & 282.0 & $2.2 \%$ & 442.6 & $3.6 \%$ \\
\hline TOTAL & $3,319.9$ & $100.0 \%$ & $8,058.6$ & $100.0 \%$ & $12,878.0$ & $100.0 \%$ & $12,416.5$ & $100.0 \%$ \\
\hline
\end{tabular}




\section{Despite modest production volumes, inverters have evolved significantly since the 1980s through manufacturer innovations and technology improvements.}

\section{0s}

Inverters were bulky, heavy, difficult to install, unreliable, and their efficiency was in the $85-90 \%$ range. They were strictly devices for converting DC to AC.

1991

The early 1990s saw the first large-scale series production of PV inverters (SMA PV-WR).

1995

First PV string inverter (SMA SB 700). Allows connection of modules in series, modular systems, higher system efficiency, and reliability. String inverter becomes most common on the market.

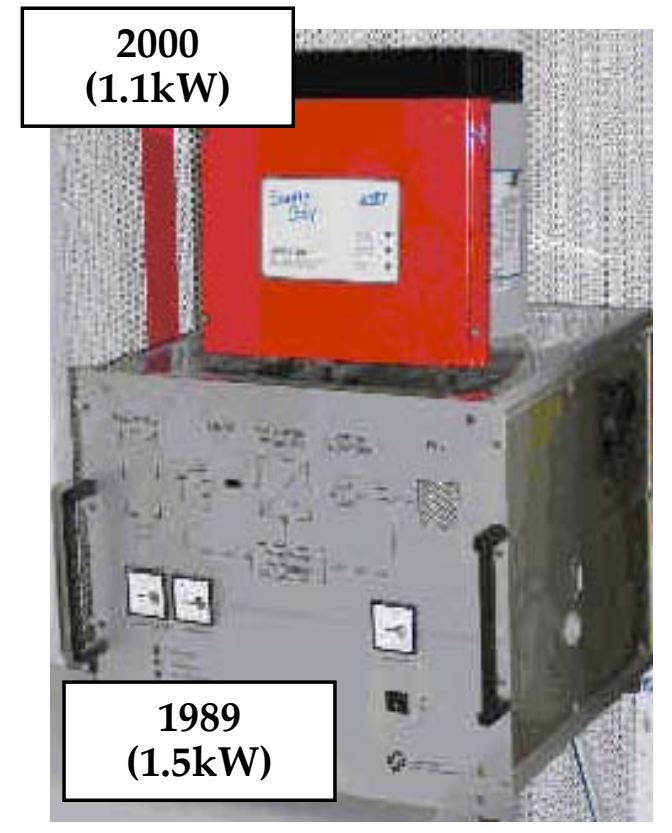

Late $\quad$ - Basic data-acquisition system, "plug-and-play" installation.

1990s - Transformerless and high frequency (HF) designs reach efficiencies above 95\%

- Reliability improves. Warranties (2-5 years) offered. 


\section{Along with a trend toward increasing sizes, inverters are becoming increasingly sophisticated, with added capabilities.}

$$
\text { Larger Size }(>2 \mathrm{~kW})
$$

- Inverter manufacturers have been increasing the size of models meant for residential and small commercial applications. New models are generally above $2 \mathrm{~kW}$ in size.

- Many manufacturers report that the typical residential installation size is in the 3-5 $\mathrm{kW}$ range, and that $10 \mathrm{~kW}$ installations are also becoming more common.

\section{Data logging, communications, and diagnostics}

- The latest inverters feature data logging and communication capabilities. Inverter manufacturers provide the software required to process the data sent by the inverter.

- Allows quick diagnostic when the system is not operating properly. It also allows the user to adjust system parameters for optimal operation.

\section{Master-Slave Configuration for Improved Efficiency at Partial Load}

- A "master" inverter controls the operation of one or two "slave" inverters, such that the slaves are brought online only when the power produced by the modules is sufficient. In this way, inverters always operate at an optimized power level to achieve higher system efficiency. 


\section{Multi-string inverters allow a single inverter to convert power input from several module strings, reducing inverter costs for PV systems.}

\section{Multi-string Capability}

- In many installations, strings of PV modules operate under different conditions, which requires a separate inverter for each string. Multi-string technology allows multiple (usually two or three) strings to be connected to a single inverter. So-called multi-string inverters feature a separate Maximum Power Point Tracker (MPPT) for each string, ensuring maximum energy yield.

- Examples of differences that can be accommodated with a single multi-string inverter are:

- Orientation

- Shading

- Number of modules

- Module type or cell type

- This feature appears to be an increasingly important one, as system sizes grow and there is a need to accommodate modules in different orientations.

- Many popular residential inverter models being used in the United States currently do not have this feature. 


\section{Historical Perspective Inverter Features » Recent Developments}

\section{Transformerless designs - popular in Germany and Japan - reduce inverter size, cost, and weight, while improving efficiency.}

\section{Transformerless / HF Design}

- The transformer in conventional inverter designs is responsible for losses of around $2 \%$ in peak efficiency and accounts for the larger part of the inverter's weight. Designs that do away with the transformer are cheaper, more efficient, and lighter.

- However, transformers also provide automatic protection against DC injection, which protects the grid in case of system malfunction. "Transformerless" designs feature additional electronics and control components to provide DC injection protection.

- High frequency (HF) transformers are a compromise between the conventional low frequency (LF) transformers and transformerless designs. HF transformers are small, lightweight, and provide electrical isolation.

- Even though manufacturers claim that transformerless inverters can be made as safe as LF designs, they cannot be installed in some countries ${ }^{1}$ :

- Issues related to galvanic protection are the most important hurdles associated with approval of their use.

- Manufacturers expect changes in regulations or in utility requirements to take time, so inverters with transformers will continue to be needed to serve many markets.

1. Transformerless inverters are not currently allowed in Spain and Italy. In the United States, the NEC now allows ungrounded PV arrays, but resistance from the utilities prevents the use of transformerless inverters. 


\section{Historical Perspective Inverter Prices » Cost vs. Price}

\section{Data on production cost are not available for inverters, so price data must be used as a proxy.}

-In the long run, price trends reflect cost trends; but, in the short run, there may be other dynamics at play that are not related to actual production costs.

- Price trends over periods of 10 years or less may not reflect cost trends accurately and should be analyzed with care and in context.

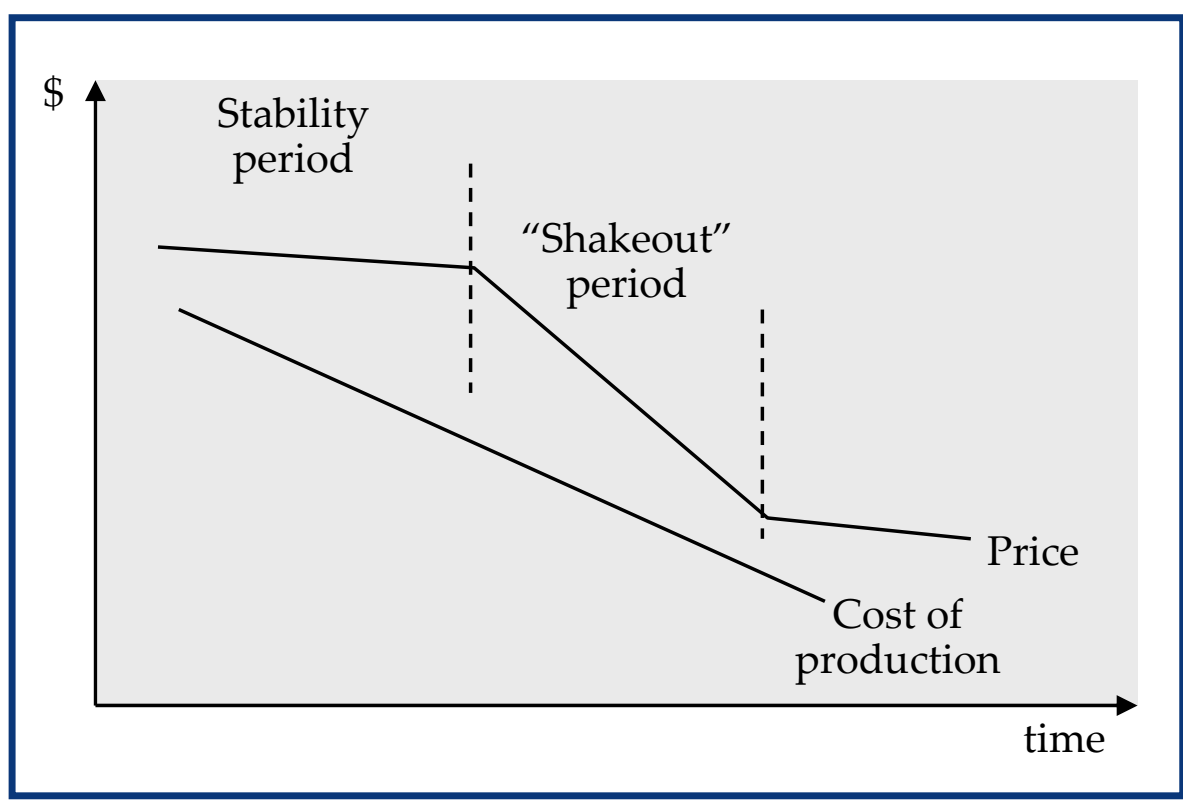

- During stability periods - where profits grow and new entrants are attracted to the market - the price trends under-represent the decrease in production cost.

- During "shakeout" periods - characterized by fierce competition, mergers, bankruptcies, and steep price declines prices can decrease faster than production costs. 


\section{Historical Perspective Inverter Prices » Determining Factors}

\section{An "average" price per $\mathrm{kW}$ is difficult to ascertain for PV inverters.}

- The rated power of the inverter is not the only factor that determines price.

$>$ The technology varies considerably from manufacturer to manufacturer, leading to differences in efficiency, size, weight, reliability, etc. These factors influence the cost of producing inverters and the price that consumers are willing to pay.

Additional features, such as a visual display, data monitoring and storage, and communication capabilities, can lead to substantial price differences between inverters of comparable rated power.

- Analysis of inverter price trends over time must take into account the evolution of inverter features.

$>$ In the past 5-10 years, inverters have evolved significantly. Reliability, ease of installation, user friendliness, efficiency, size and weight, etc. have all improved significantly. As a result, a simple analysis of $\$ / \mathrm{kW}$ prices is not representative of the real improvement in inverters.

- Inverter size has an important impact on cost. For instance, a $3 \mathrm{~kW}$ inverter is about $50 \%$ cheaper than a $1 \mathrm{~kW}$ unit on a $\$ / \mathrm{kW}$ basis. So, even within a relatively narrow size range, a single average $\$ / \mathrm{kW}$ figure inevitably hides large variations. 


\section{Inverter prices reported by SEPA for the TEAM-UP initiative were in the $\$ 1.50 / \mathrm{kW}$ to $\$ 2.00 / \mathrm{kW}$ range for residential applications. ${ }^{1}$}

- From 1996 to 2000, 644 residential installations were put in place, although inverter price data was not reported for all installations.

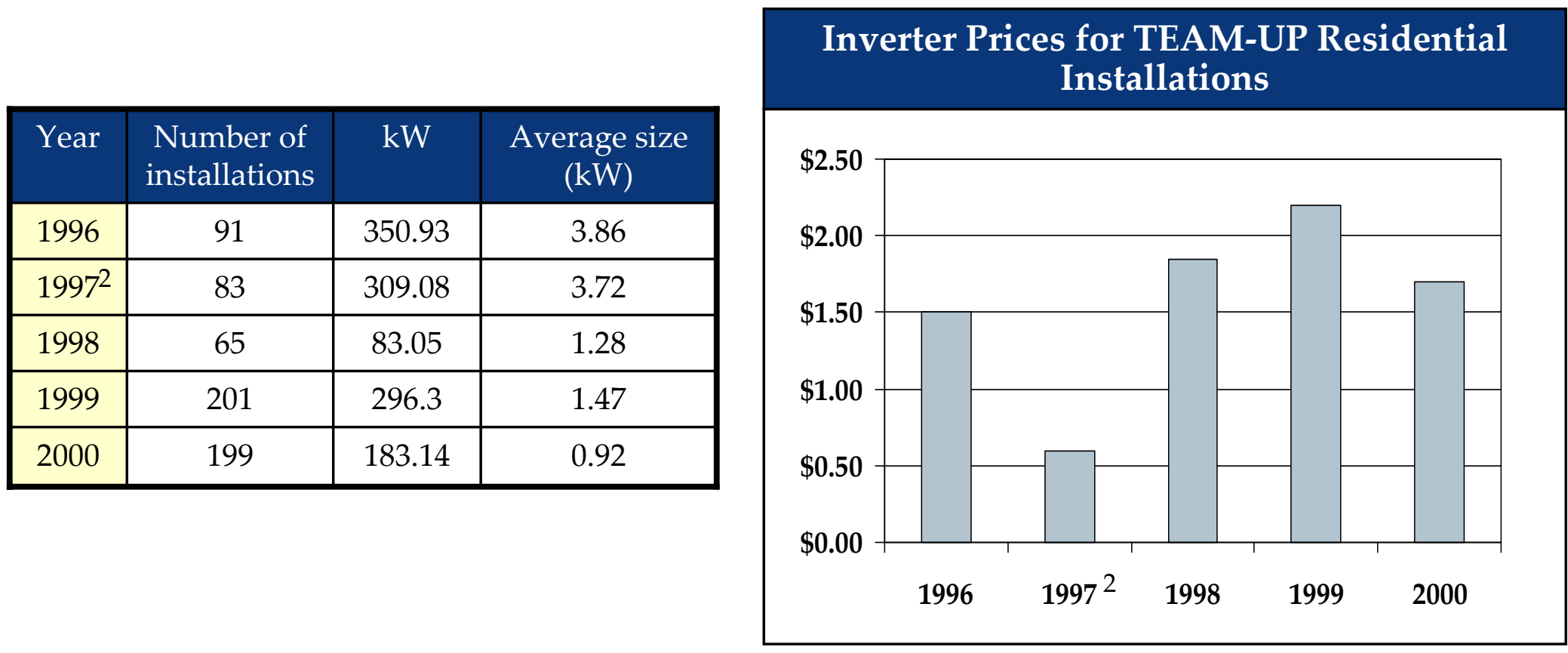

1. From to 2001, the Solar Electric Power Association (SEPA) managed TEAM-UP, a cost-sharing program funded by DOE to promote grid-tied PV installations.

2. Inverter prices reported for 1997 by SEPA for the TEAM-UP initiative were later determined not to be reported accurately. The data was also not available for the entire sample size. Because of limitations in sizes of available inverters, many were oversized and cost reported on $\$ / \mathrm{kW}$ basis may not accurately reflect the true selling prices being used at the time.

Source: Reference 14 


\section{Inverter prices for larger installations $(>70 \mathrm{~kW})$ for TEAM-UP were generally in the $\$ 0.40 / \mathrm{kW}$ to $\$ 0.80 / \mathrm{kW}$ price range.}

- From 1996 to 2000, 23 systems ranging from $70 \mathrm{~kW}$ to $400 \mathrm{~kW}$ were installed.

\begin{tabular}{|c|c|c|c|}
\hline Year & $\begin{array}{c}\text { Number of } \\
\text { installations }\end{array}$ & $\mathrm{kW}$ & $\begin{array}{c}\text { Average size } \\
(\mathrm{kW})\end{array}$ \\
\hline 1996 & 2 & 317.2 & 158.60 \\
\hline 1997 & 4 & 478.4 & 119.60 \\
\hline 1998 & 7 & 648.1 & 92.59 \\
\hline 1999 & 4 & 393.6 & 98.40 \\
\hline 2000 & 6 & 1029.4 & 171.57 \\
\hline
\end{tabular}

Inverter Prices for TEAM-UP Commercial Installations

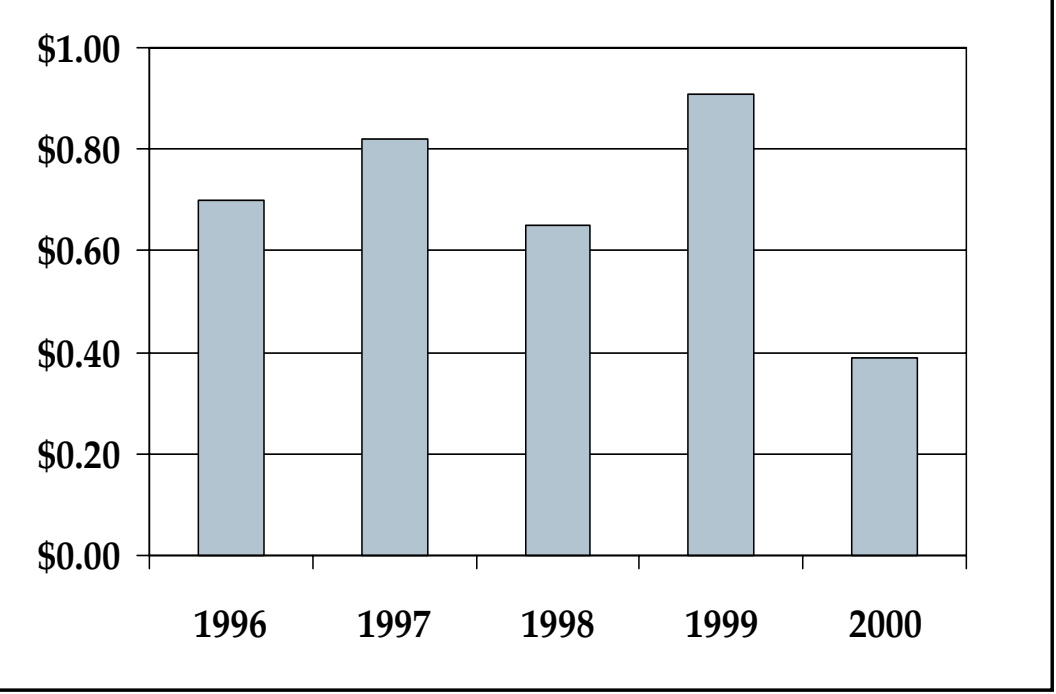




\section{In 2004, prices for small inverters $(<10 \mathrm{~kW})$ in the United States ranged from $\$ 0.67 / \mathrm{W}$ to $\$ 2.67 / \mathrm{W}$. In 2005 , they ranged from $\$ 0.48 / \mathrm{W}$ to $\$ 2.42 / \mathrm{W}$.}

$\Rightarrow$ Our data indicates that U.S. prices have dropped by roughly $10 \%$ in the past year.

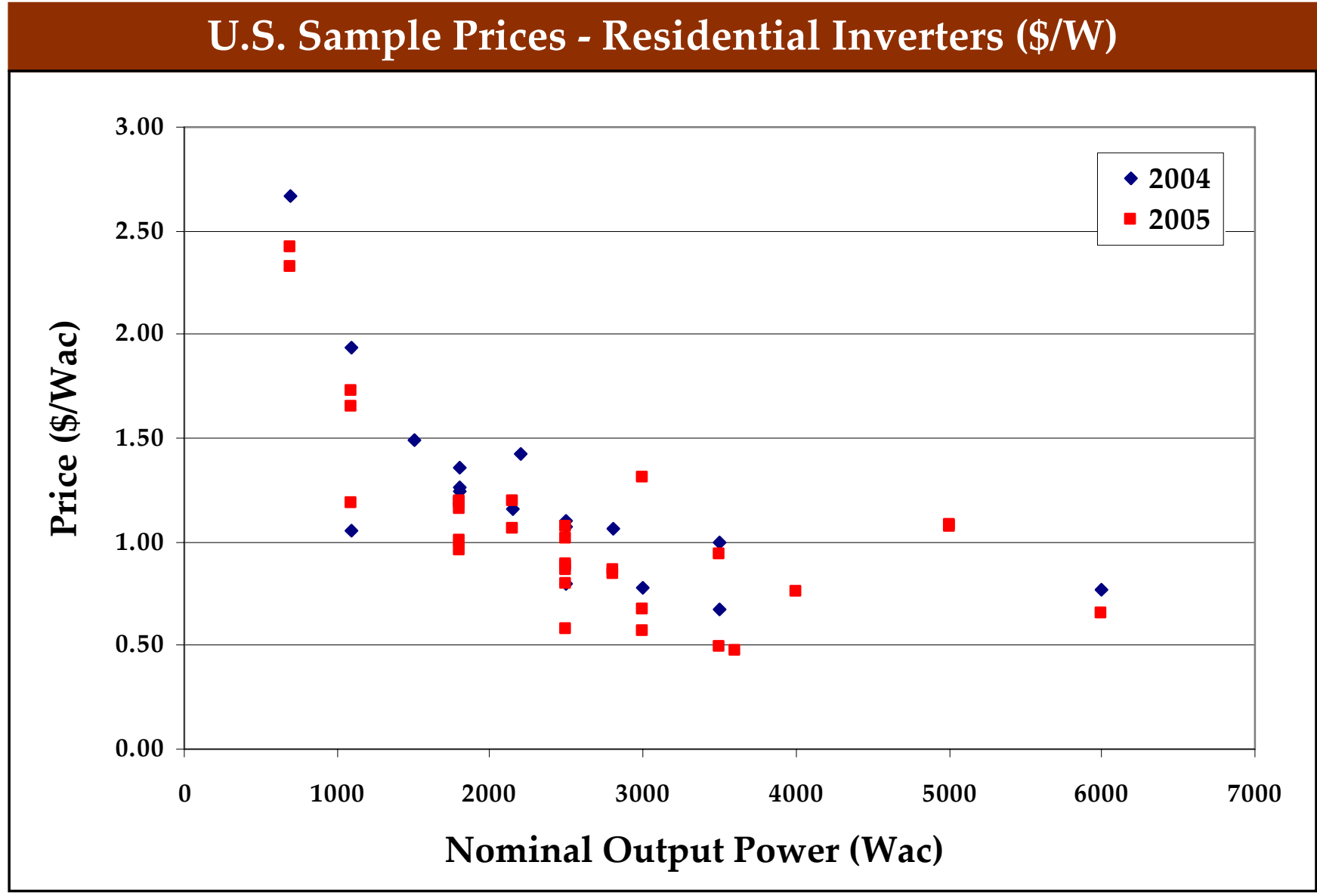

Each point on the chart represents a particular model's average online retail price at the time of the survey. 


\section{Historical Perspective Inverter Prices » Solarbuzz Data}

\section{Solarbuzz tracks average inverter prices in Europe and the United States}

- During the past 2 years, prices have fallen by about 13\% in Europe.

- Contrary to NCI data, Solarbuzz reports stable prices in the United States.

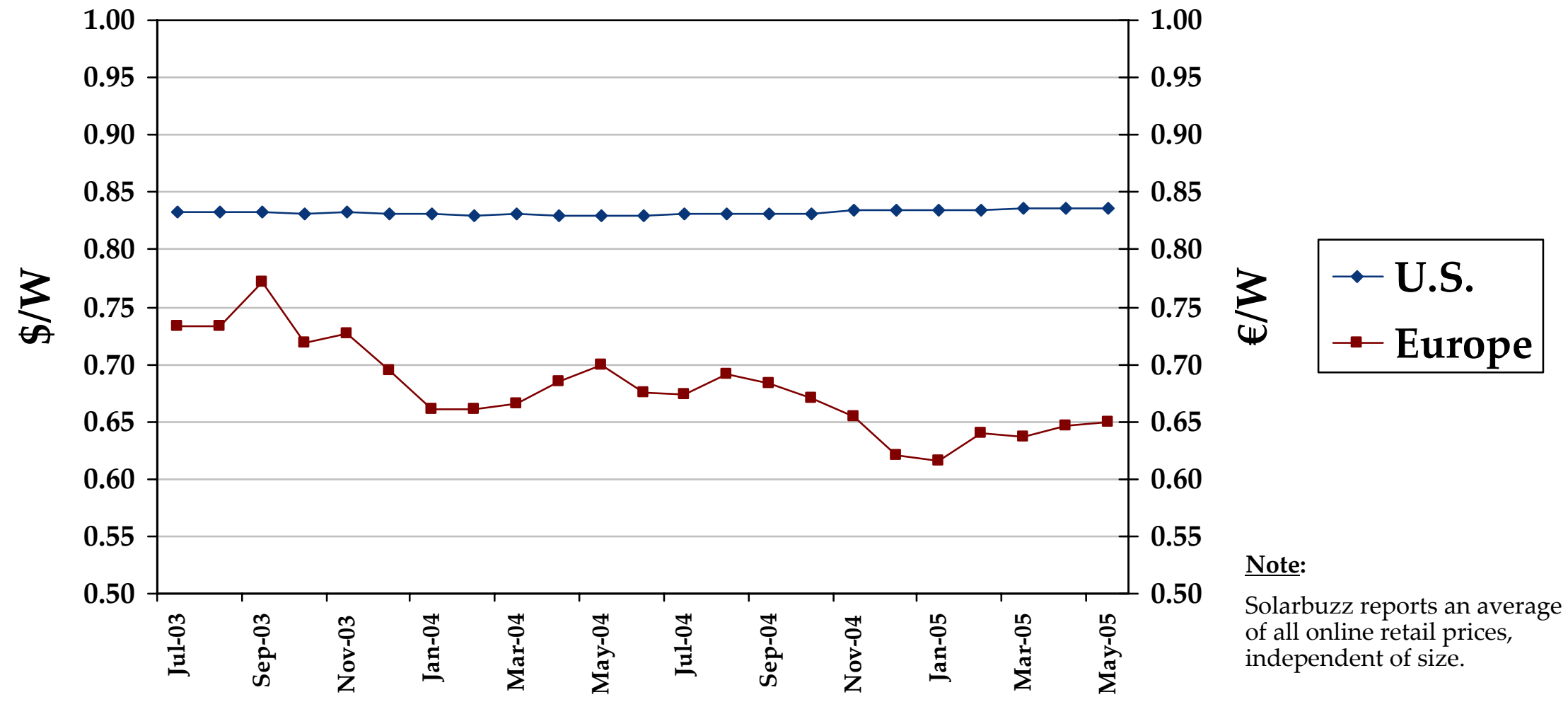




\section{The IEA PVPS program conducted surveys of PV inverters in 1998 and 2002 for U.S., European, and Japanese manufacturers.}

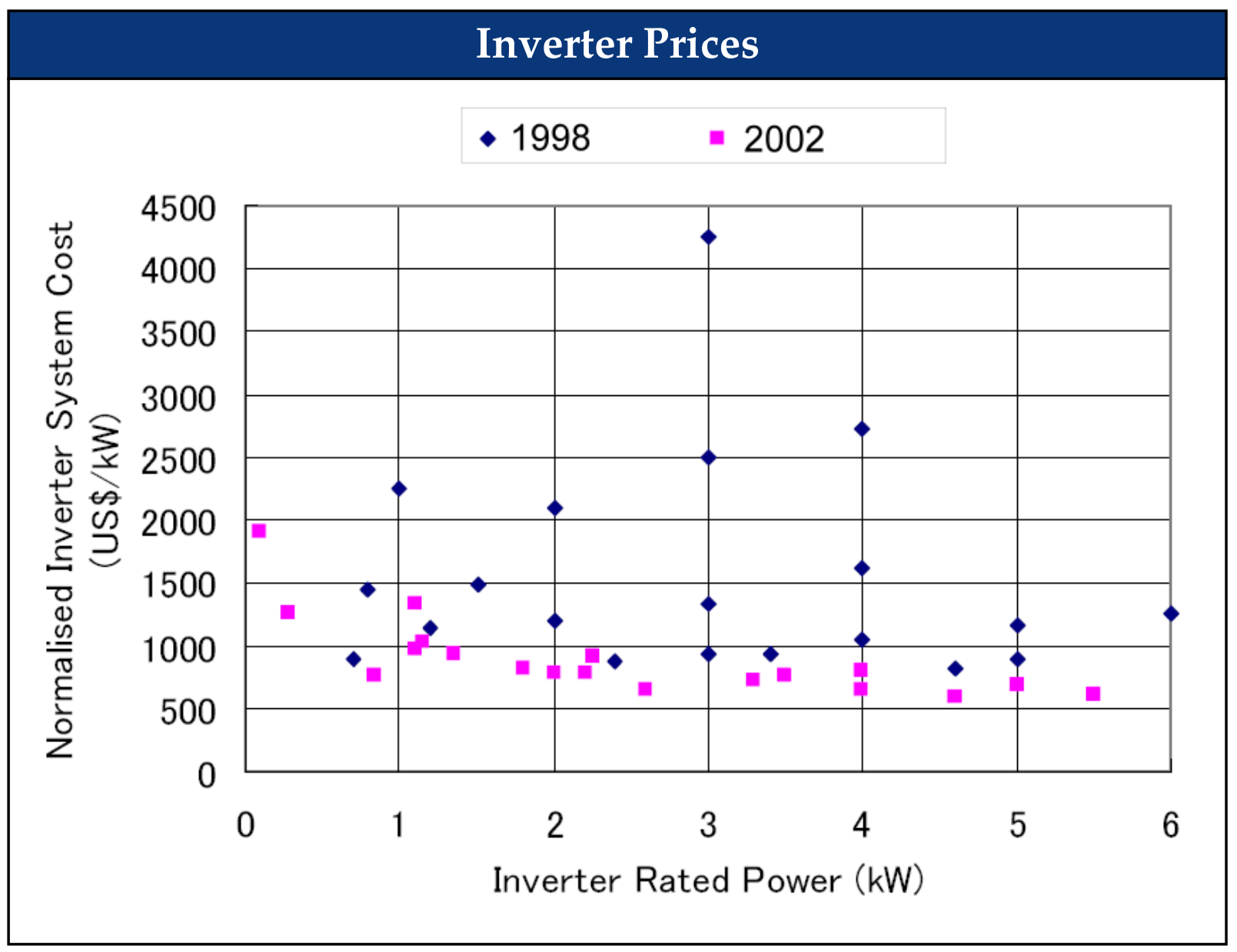

- From 1998 to 2002:

- The general price level of inverters fell by about $40 \%$.

- Outliers with excessively high prices were completely eliminated from the market.

\section{Source: Reference 11}

Note:

Each point on the chart represents a particular model's average retail price at the time of the survey. 
IEA PVPS data shows that smaller inverters $(\sim 1 \mathrm{~kW})$ have a volume of about $15 \mathrm{~L} / \mathrm{kW}$, whereas larger ones $(\sim 5 \mathrm{~kW})$ are around $5 \mathrm{~L} / \mathrm{kW}$.

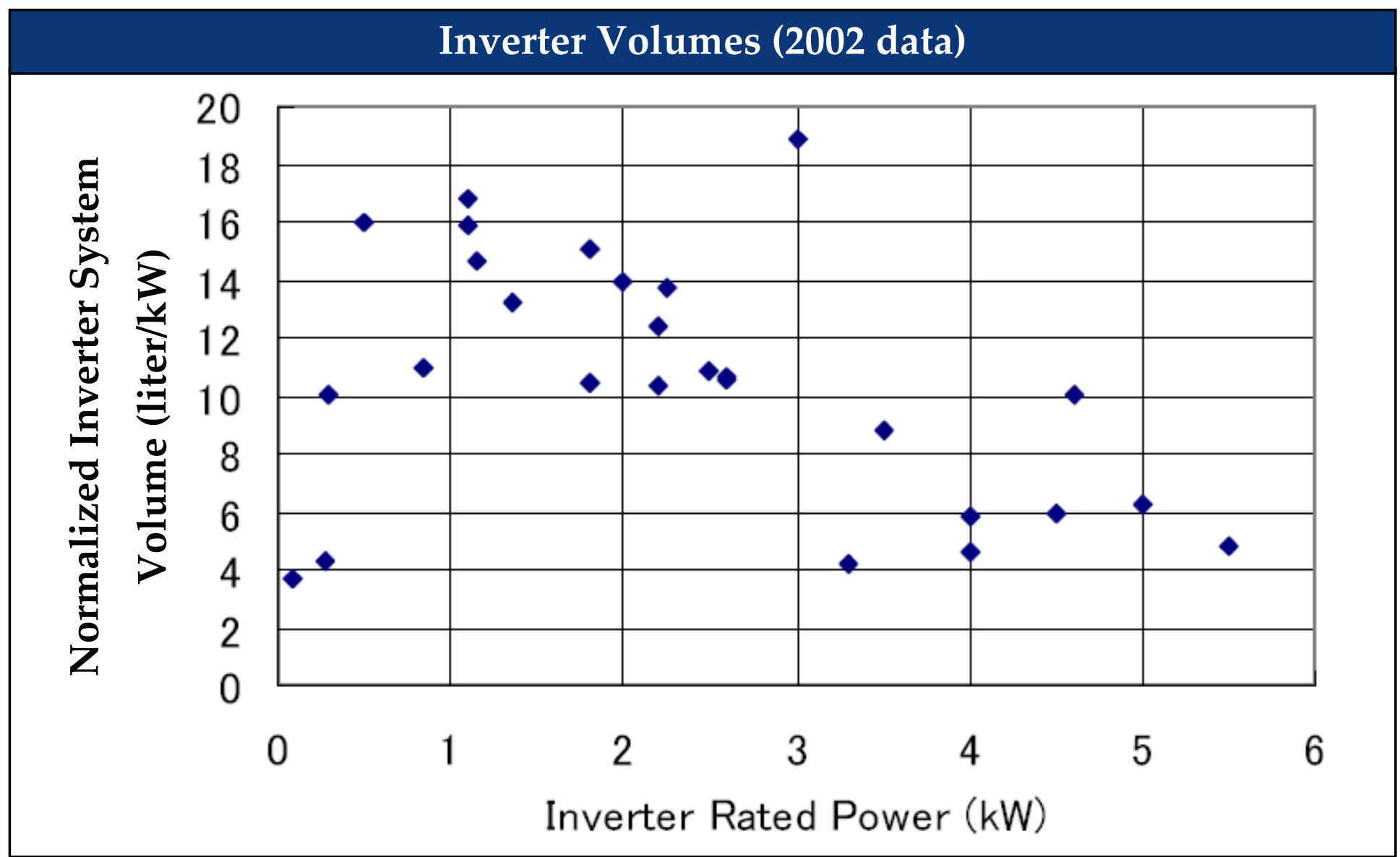




\section{IEA PVPS data shows that the weight of transformerless and HF inverters $(\sim 5 \mathrm{~kg} / \mathrm{kW})$ is $50-75 \%$ less than that of $\mathrm{LF}$ units.}

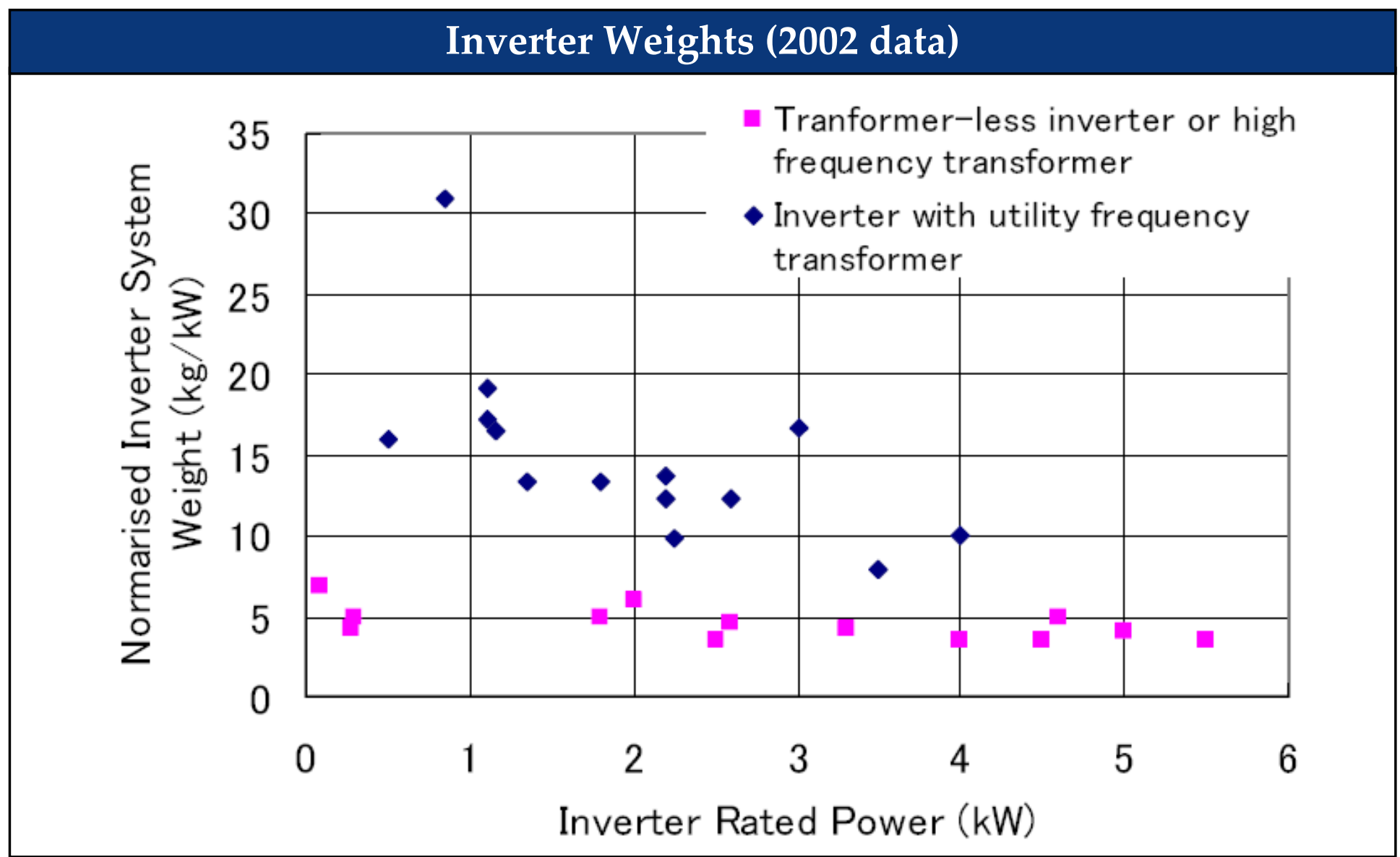




\section{Inverter reliability has an impact on life-cycle cost. Efforts targeting inverter cost reductions should consider reliability improvements.}

- The inverter accounts for $10-20 \%$ of the initial system cost.

- Inverters generally need to be replaced every 5-10 years, whereas modules and other system components have a life of 25 years or more.

»Investment in a new inverter is required 3-5 times over the life of a PV system.

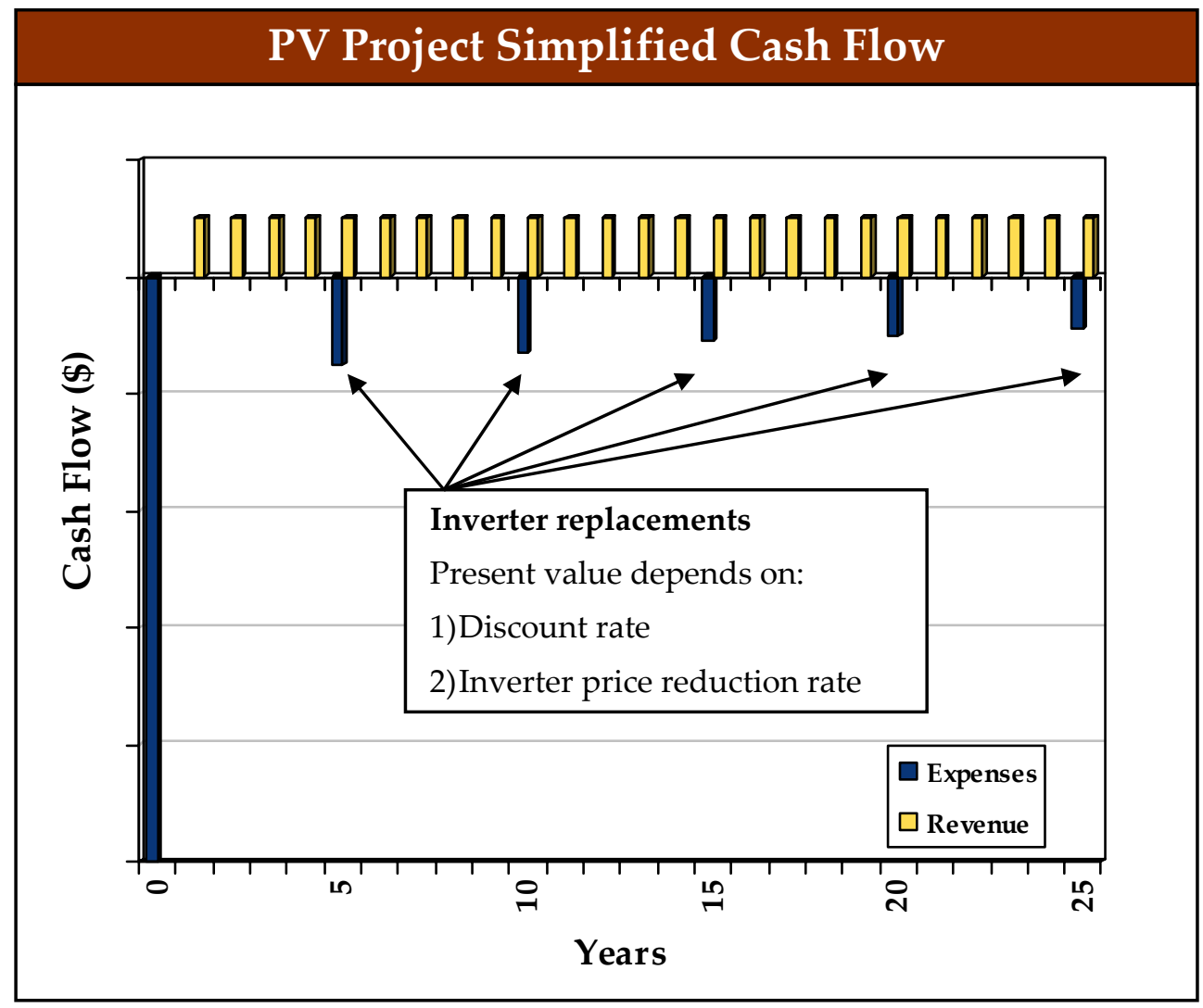

Assumes expenses on other parts of the PV system are small. 


\section{NCI analysis indicates that the benefits of designing inverters that can operate for 10-15 years or more before replacement are limited.}

\section{NPV of life-cycle cost / initial system cost}

Discount rate $=5 \% ;$ Price reduction rate $=5 \%$

\begin{tabular}{|c|c|c|c|c|}
\hline \multirow{2}{*}{$\begin{array}{c}\text { Inverter cost } \\
(\% \text { initial } \\
\text { system) }\end{array}$} & \multicolumn{4}{|c|}{ Inverter replacement interval } \\
\cline { 2 - 5 } & 5 & 10 & 15 & $25+$ \\
\hline $10 \%$ & $114.1 \%$ & $105.0 \%$ & $102.2 \%$ & $100 \%$ \\
\hline $15 \%$ & $121.2 \%$ & $-107.5 \%$ & $103.3 \%$ & $100 \%$ \\
\hline $20 \%$ & $128.3 \%$ & $110.1 \%$ & $104.5 \%$ & $100 \%$ \\
\hline
\end{tabular}

Discount rate $=10 \%$; Price reduction rate $=10 \%$

\begin{tabular}{|c|c|c|c|c|}
\hline \multirow{2}{*}{$\begin{array}{c}\text { Inverter cost } \\
(\% \text { initial } \\
\text { system) }\end{array}$} & \multicolumn{4}{|c|}{ Inverter replacement interval } \\
\cline { 2 - 5 } & 5 & 10 & 15 & $25+$ \\
\hline $10 \%$ & $105.8 \%$ & $101.5 \%$ & $100.5 \%$ & $100 \%$ \\
\hline $15 \%$ & $108.6 \%$ & $102.3 \%$ & $100.7 \%$ & $0 \%$ \\
\hline $20 \%$ & $111.5 \%$ & $103.1 \%$ & $101.0 \%$ & $10 \%$ \\
\hline
\end{tabular}

\section{Assuming an initial PV system cost of $\$ 8 / \mathrm{W}$ :}

NPV of lifecycle cost $(\$ / W)$

$9.70 \rightarrow 8.60 \rightarrow 8.26$
NPV of lifecycle cost $(\$ / W)$

$8.69 \rightarrow 8.18 \rightarrow 8.06$

The benefits of increased reliability must be weighted against the added cost.

Note: If one assumes that an inverter can be repaired instead of replaced, this would bring down the NPV contribution of the inverter and yield figures lower than the ones shown above. 


\section{Historical Perspective Inverter Reliability}

\section{The economics of long-life inverters are doubtful, but other considerations can change this conclusion.}

- Based on NPV calculations, the case for developing inverters that can last more than 10 years appears weak.

- The behavior of consumers, who focus mainly on first cost and tend to require short payback periods, suggests that the discount rate to be used with residential PV systems is high. This favors inverter development focused on first cost rather than extended lifetime.

\section{However:}

- If consumers who are buying PV systems today are not aware of the future liability associated with replacing or repairing an inverter, the frustration caused by this unexpected and significant expense could lead some consumers to abandon their systems, and it could tarnish the image of PV.

- This is particularly a concern where adoption of PV is based on large rebates: In California, where consumers sometimes pay as little as 10\% of the initial cost of a PV system, the expense associated with replacing the inverter can be very significant compared to the first cost of the system.

$>$ Will consumers be eligible for a rebate on replacement inverters? 


\section{Reliability of inverters is still inadequate, but improvements are being made.}

$\sum \quad \begin{aligned} & \text { Inverter mean time between failure (MTBF) is reported to be in the range } \\ & \text { of } 5 \text { to } 10 \text { years. }{ }^{*} \text { This short MTBF has a significant negative impact on the } \\ & \text { competitiveness of PV systems and will inhibit expansion of PV. }\end{aligned}$

\section{Recent improvements in reliability:}

-In recent years, almost every manufacturer of PV inverters has improved their devices' expected lifetime substantially. ${ }^{2}$

-A 5-year warranty has become the norm in the industry, whereas 2-year warranties were most common just a few years ago.

- These longer warranties are somewhat controversial. The manufacturers who offer them claim that they have gained a better understanding of the causes of inverter failures by collecting and studying field data, that they have reduced part count, incorporated higher quality components, and modified product design to lessen component stress where vulnerabilities were identified. Other manufacturers and industry experts assert that these warranties are mere marketing tools.

- Manufacturers currently are evaluating offering extended warranties that would be available for an additional cost. This has become common for other types of appliances, and is a way for consumers to reduce risk associated with near-term failures.

1. Reference $8 .{ }^{*}$ Note: MTBF is indicative of inverter economic life. It is a calculated number based on statistically determined reliability numbers assigned to each component used in a design, and depends on the stress and thermal environment. 


\section{Historical Perspective Inverter Reliability » Recent Developments}

\section{In the past year, North American manufacturers have introduced innovative products and set new standards for inverter reliability.}

- PV Powered (PVP) of Oregon and Sustainable Energy Technologies (SET) of Canada offer a 10-year warranty, the best available in the industry.

-PVP and SET inverters have a lower part count than other products available on the market today, ${ }^{*}$ which increases reliability because:

1. Fewer parts mean fewer failures.

2. Higher-quality parts can be used while still meeting inverter cost targets.

- Both manufacturers use Digital Signal Processing (DSP).

- A DSP chip translates the waveform into digital format, which can then be processed, evaluated, and modified in very short time periods. As a result, the inverter can respond quickly to a wide range of situations, which improves reliability and efficiency.

* Note: Other manufacturers point out that different methods of counting parts may be somewhat misleading. 


\begin{tabular}{|c|l|}
\hline 1 & Executive Summary \\
\hline 2 & Introduction \\
\hline 3 & Historical Perspective \\
\hline 4 & Future Performance and Cost Estimates \\
\hline 5 & Challenges for Achieving Future Targets \\
\hline 6 & Addressing Challenges \\
\hline 7 & Suggested Role for Government \\
\hline
\end{tabular}




\section{Experience curves model the relationship between cost of production and production volume, which indicates the level of experience.}

Basic Assumption: Cost of production declines by a constant percentage with each doubling of the total number of units produced. This cost-reduction rate is called the learning rate (LR) and ranges from $0 \%$ to $35 \%$ across various technologies.

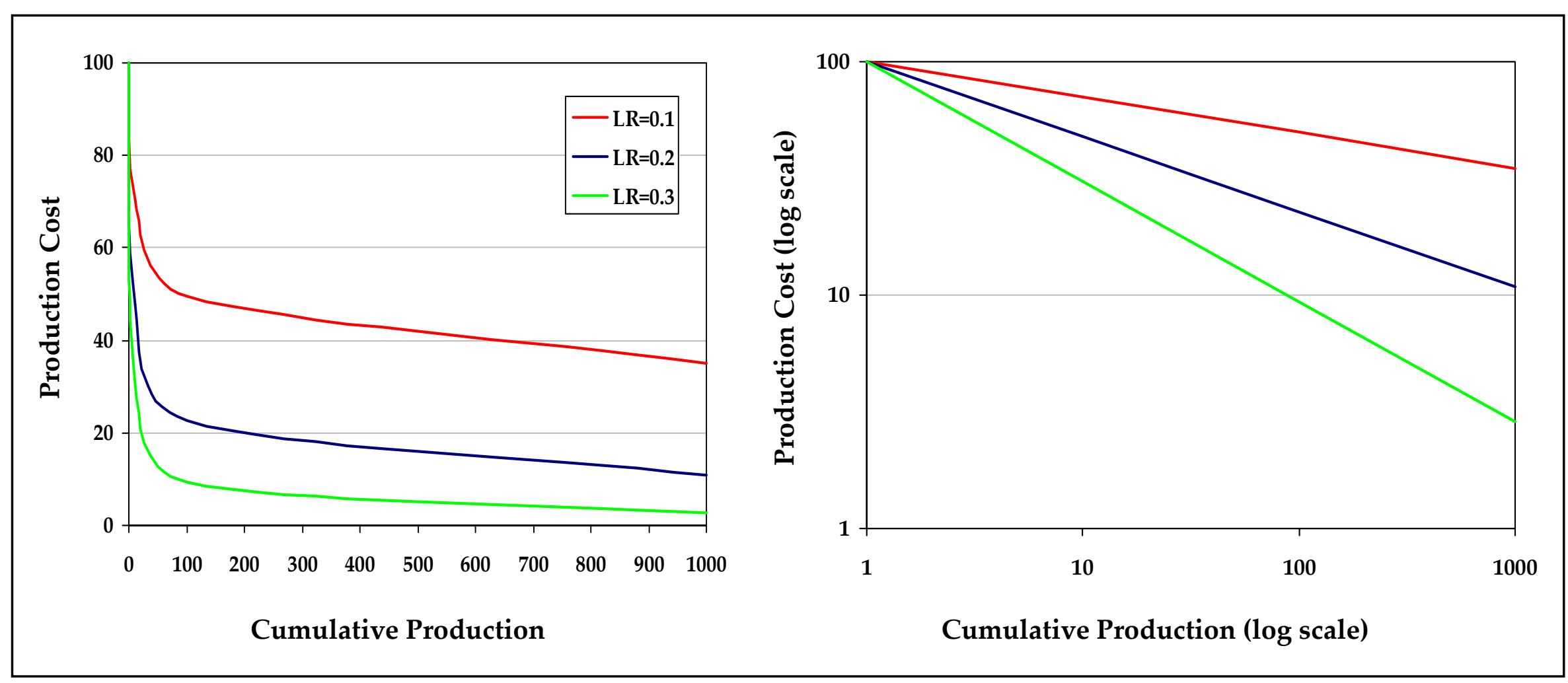




\section{Future Performance Experience Curve » Results for PV}

\section{The learning rate for PV modules and balance-of-system is about $20 \%$. For inverters, however, the learning rate appears significantly lower.}

A comprehensive EU-supported study of prices and production volumes for PV modules and BOS found that the learning rate in the PV industry is in the $20 \%-25 \%$ range.

$\rightarrow$ For inverters, the learning rate is significantly lower: approximately $10 \%{ }^{1}$

- This figure does not give a complete picture of inverter improvements for two reasons:

1. This learning-rate estimate is based on inverter prices, or up-front costs (on a $\$ / \mathrm{kW}$ basis), rather than life-cycle cost. Therefore, improvements in efficiency and reliability - which improve inverter life-cycle costs - are not taken into account.

2. Other inverter improvements (e.g. reductions in weight and size, LCD displays, plug-and-play, multi-string, etc.) are also not taken into account.

- In addition, it must be noted that this result is based on an analysis of prices over the 1995-2002 period, because of insufficient data prior to 1995. As a result, the learning rate obtained is subject to significant uncertainty, because trends in inverter prices may not reflect trends in production costs accurately over periods of fewer than 10 years. 


\section{Data used to estimate the learning ratio for inverters was taken from inverter retail prices in the Netherlands and in Germany (1995-2002).}

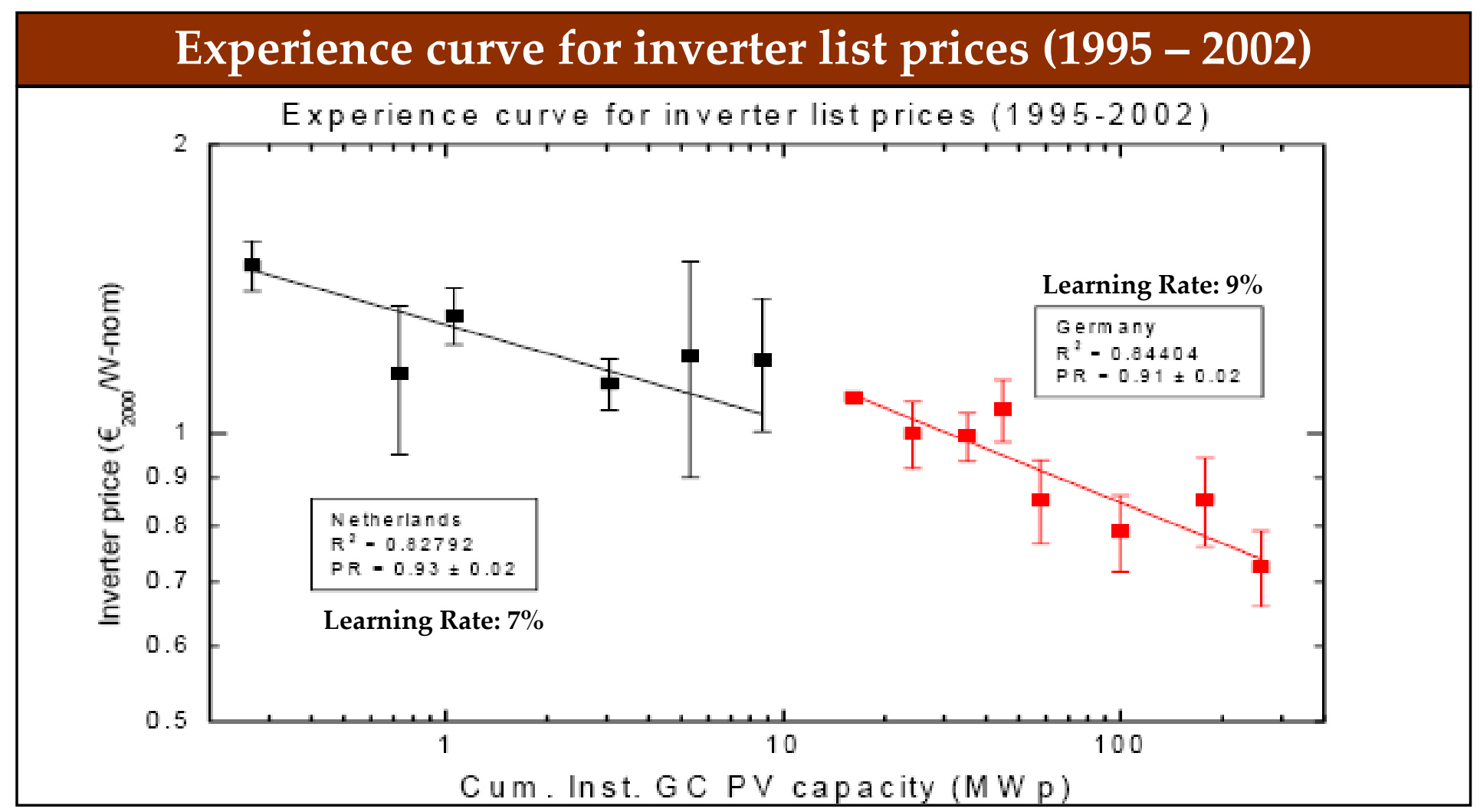

Note: The Progress Ratio (PR) is related to the Learning Ratio (LR): PR = 1-LR 


\section{Future Performance Experience Curve » Discussion of Inverter Data}

\section{Until recently, the markets for inverters in each country were very separate, but this situation is changing, particularly in Europe.}

- Market boundaries: For PV inverters, differences in regulations between countries have hindered the emergence of a global market. During the period of 1995-2002, most manufacturers served only one country.

$>$ The extent of the "Learning System" for inverters was national, which is why the learning rate was obtained on the basis of installed capacity at the national level.

Note: Germany and the Netherlands were selected, because the data available for other countries was insufficient.

- Today, the market for inverters can be broadly segmented among Japan, Europe (mostly Germany), and the United States. It has internationalized somewhat in recent years, with several manufacturers serving more than one of the above segments. However, it should be noted that manufacturers serving multiple markets typically offer different products in each market.

Going forward, the learning system for inverters will become increasingly international, especially across European countries. This trend will be less marked in the United States, because of the level of state control of regulations. 


\section{Future Performance Experience Curve » Discussion of Inverter Data}

\section{Production volumes can be measured in units or megawatts, but using megawatts is a more practical alternative.}

- Production volumes: The Photex study measured production in MW rather than in number of units. The fact that historical data and projections of PV installed capacity are generally available in MW is a strong argument in support of this methodology.

- Because average inverter sizes have generally been increasing (from $<2 \mathrm{~kW}$ to $>3-5 \mathrm{~kW}$ ), the learning rate would be higher, if it was based on number of units rather than MW. This is because the growth rate as measured in units produced has been lower than the growth rate in MW, but the observed prices are obviously not affected by how production is measured.

$$
\mathrm{LR}_{\text {units }}>\mathrm{LR}_{\mathrm{MW}}
$$

- If the analysis is done based on units, then $\mathrm{LR}_{\text {units }}$ would have to be applied to projections of units produced, which would require making an assumption concerning future trends in inverter sizes.

If the past trend of increasing inverter sizes is assumed to continue, then the price projections would be the same whether the learning curve analysis is based on units or MW.

If inverter sizes are assumed to stabilize, then the learning-curve analysis based on units would forecast lower prices. This is because $\mathrm{LR}_{\text {units }}>\mathrm{LR}_{\mathrm{MW}}$, while the growth rate in units would be the same as the growth rate in MW. *

Future trends in inverter sizes cannot be determined with a great degree of certainty. Given the great number of factors that influence inverter prices and the high uncertainty involved in a learning-curve analysis, adding this extra step to the analysis is not likely to improve results.

* NOTE: Inverter prices have been decreasing partly because size has been increasing. Hence, if inverter sizes are assumed to stabilize in the future, the learning rate inferred from past prices will be too high when applied to future production. This is true whether the analysis is based on units or $\mathrm{MW}$, i.e. $\mathrm{LR}_{\text {units }}$ or $L R_{\mathrm{MW}}$ would both be too high. But the fact remains that $L R_{\text {units }}>\mathrm{LR}_{\mathrm{MW}}$ (they do not change, because they are based on historical data and are therefore independent of our assumptions about future size trends), so a learning-curve analysis based on units would forecast lower prices than an analysis based on MW. But both analyses would overstate the price reductions, if inverter sizes are assumed to stabilize in the future. 
Using a $20 \%$ growth rate in annual sales and a learning rate of $10 \%$, inverter prices would drop by about $35 \%$ in 10 years and $50 \%$ in 20 years.

U.S. PV Inverter Prices - Learning Curve Projections

Projections for Various Learning Rates and Industry Growth Rates (2005-2025)
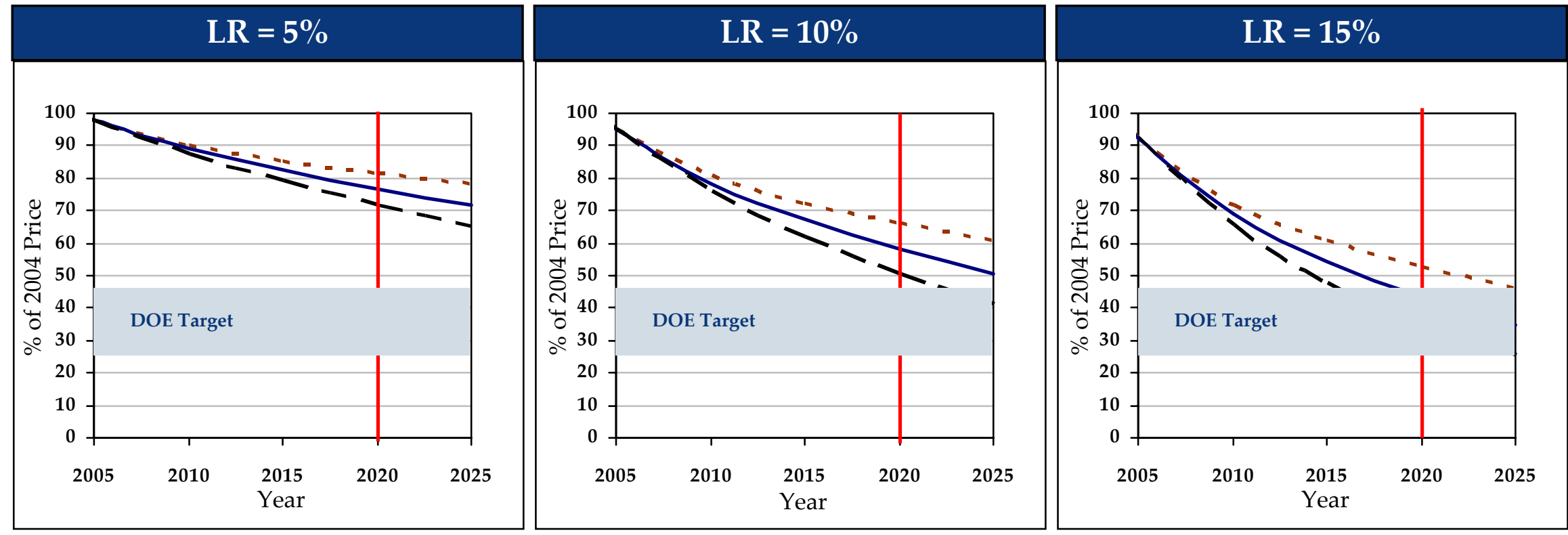

Annual Sales Growth Rate:

$10 \%$

$20 \%---30 \%$

Assumptions:

Installed capacity as of the end of 2004: $163 \mathrm{MW}$

Sales in 2005: $64 \mathrm{MW}$ 


\section{Price projections based on world inverter sales yield results that are nearly identical to the U.S. case.}

World PV Inverter Prices - Learning Curve Projections

Projections for Various Learning Rates and Industry Growth Rates (2005-2025)
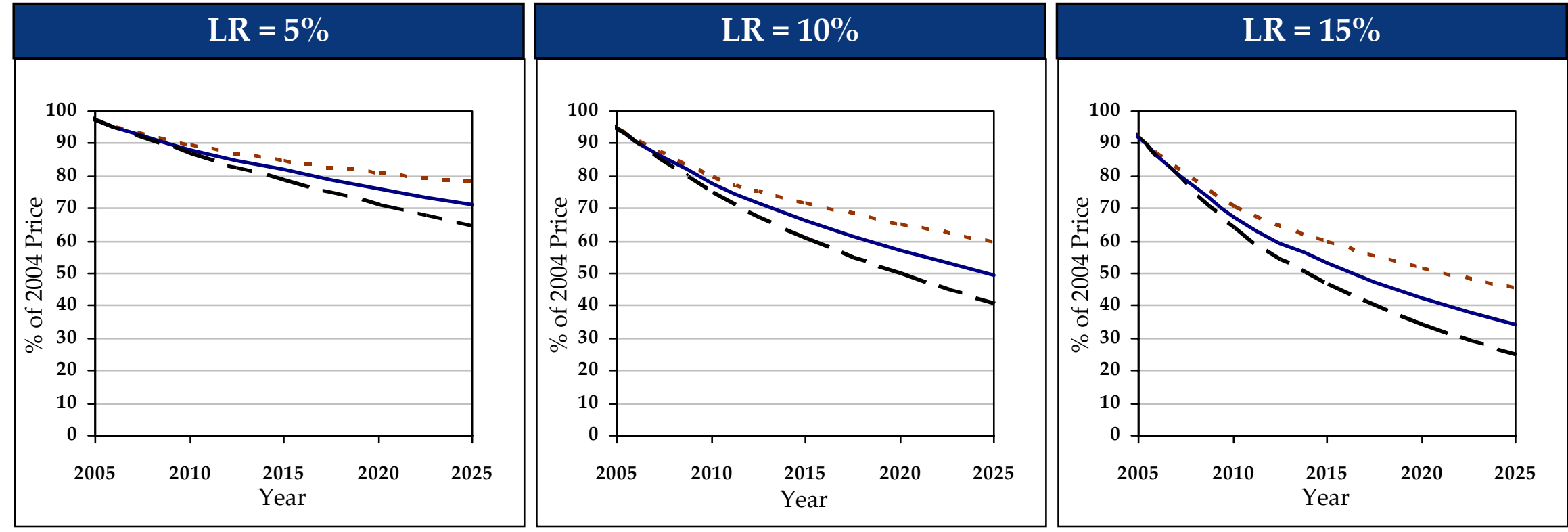

Annual Sales Growth Rate:

$10 \%$

$20 \%---30 \%$

Assumptions:

Installed capacity as of the end of 2004: 2,080 MW

Sales in 2005: $908 \mathrm{MW}$ 


\section{Based on NCI analysis of learning-curve rates, we believe $10 \%$ is a reasonable estimate for both the U.S. and international inverter markets.}

- Our central estimate for the learning rate is $10 \%$, which is slightly higher than the $7-9 \%$ figure obtained by the PHOTEX study. We believe the learning rate is likely to go up in the future for the following reasons:

1. Consolidation: As the inverter market matures, smaller manufacturers will be rooted out and a limited number of manufacturers will take over larger market shares. As these manufacturers benefit from increasing volumes, learning effects are likely to accelerate.

2.Globalization: As manufacturers expand into new markets becoming global suppliers, they will benefit from larger sales volumes. In addition, having a foothold in several markets will limit their exposure to unpredictable policy changes, which should promote investment. The eventual harmonization of standards regarding PV installations, interconnection, and inverters will help to accelerate this trend.

- The high degree of similarity between U.S. and world projections is due to the fact that world and U.S. PV markets are both growing at a similar rate: The sales forecast for 2005 represents about $40 \%$ of installed capacity for the United States, while the figure is only slightly higher for the world, at $44 \%$. Should the market growth rates diverge in the future, inverter price trends may differ more significantly between the U.S. and world markets. 


\section{Our central estimate based on learning-curve projections shows inverter prices going down by about $42 \%$ by 2020 .}

- This assumes a $20 \%$ per annum market growth and a $10 \%$ learning curve.

The DOE target for inverter prices is $\$ 0.25-0.30 / \mathrm{W}$ by 2020 .

$>$ If the basis for current inverter prices is taken as $\sim \$ 1.00 / \mathrm{W}$, which is representative of inverters in the 1-3 $\mathrm{kW}$ size range, then the price forecast for 2020 is $\$ 0.58 / \mathrm{W}$, or about twice the DOE target.

$>$ If the basis for current inverter prices is taken as $\sim \$ 0.65 / \mathrm{W}$, which is representative of inverters in the 3-6 $\mathrm{kW}$ size range (Xantrex GT 3.0, SMA SB 6000), then the price forecast for 2020 is $\$ 0.38 / \mathrm{W}$, still about $30 \%$ higher than the DOE goal.

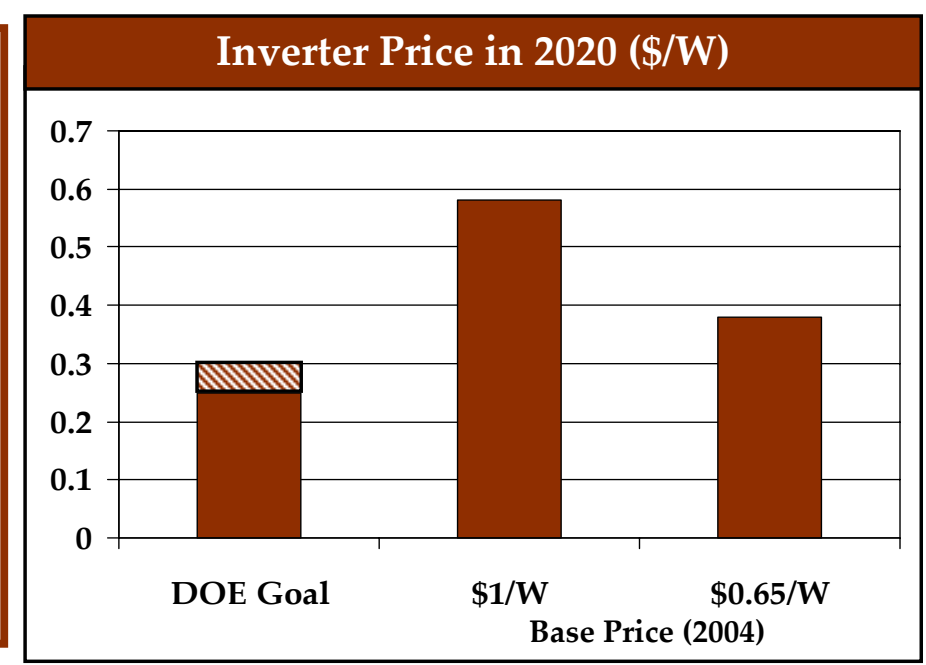

- However, additional features and other technology improvements have been added over time, such as data logging capabilities, communications and controls, and others. Additional features are likely to be added in the future. Therefore, it is difficult to compare inverter prices over time, as the products are not uniform.

- Therefore, while the DOE goal may appear difficult to achieve on the basis of typical learning-curve improvements, it is likely that future products will provide additional customer benefits. 


\section{Inverter manufacturers have diverging cost expectations, and projections made in the past have generally been inaccurate.}

-SMA stated in mid-2004 that it wanted to reduce inverter prices by $50 \%$ by the end of 2006. ${ }^{1}$ The observed evolution in inverter prices since then suggests that it is highly unlikely that this objective will be obtained. However, it is interesting to note that SMA further stated that:

$\Rightarrow$ Cost reductions to less than $€ 250 / \mathrm{kW}$ did not seem possible with current technologies. Break-through technologies that may enable further cost reductions beyond 2010 were module-integrated inverters, high-frequency converters, and high-voltage converters.

-More recently, SMA has stated that their goal for inverter costs was to bring down the specific price $(\$ / \mathrm{kW})$ by $50 \%$ every five years. ${ }^{2}$

- Photon International reports that inverter prices have gone down by $7 \%$ from 2004 to 2005 and that most manufacturers expect costs to decrease by $15-25 \%$ during the next 5 years ${ }^{3}$. However, expectations vary across manufacturers:

$\Rightarrow$ Exendis expects reductions of more than 30\% during the next 5 years.

$\Rightarrow$ Sun Power foresees only slight reductions in cost in the near future and expects inverter prices to stabilize, at least for the next few years. 


\section{Inverter manufacturers do not think that lifetime on the order of 20 years is achievable in the near term...}

- Xantrex, Managing Director: “Why make inverters with a longer life when the customer is better off replacing the inverter every 10 years or so anyway? The inverters available in 10 years will be better products with higher efficiency."

- SMA America, President: "Why focus on higher reliability? Our customers worry only about firstcost. In any case, it's more cost-effective to just replace the inverter in 10 years."

- Sustainable Energy Technologies, Director of Operations: "A 20-year lifetime for PV inverters is at least 10 years away."

- Mitsubishi: "A 20-plus-year life for inverters is impossible. Some parts of the inverters would need to be replaced over such an extended period."

- SMA, Head of Solar: "A 20-year lifetime is not possible."

- Fronius, Head of Sales (Germany): "Inverter MTBF may reach 12 years by 2015. A 20-year lifetime can't be achieved."

- GE Energy indicated that 20-year life would not be practical without a significant impact on cost. A 15-year life is more reasonable, and that should be reviewed based on life-cycle costs impact.

- Contrary to statements made in a recent Photon International article (April 2005), manufacturers and other industry experts we spoke to do not believe that capacitor improvements alone will result in inverters that can "keep going for more than 20 years."

... and most interviewed by NCI do not see this as a reasonable target. 


\section{Next-generation inverters will enhance the competitiveness of PV through lower cost, higher reliability, and better performance.}

\begin{tabular}{|l|l|}
\hline \multicolumn{1}{|c|}{ Feature } & \multicolumn{1}{c|}{ Dext-Generation Inverter } \\
\hline $\begin{array}{l}\text { Higher } \\
\text { Efficiency }\end{array}$ & $\begin{array}{l}\text { - Currently, maximum efficiencies are on the order of 95\% for U.S. inverters. In Europe, } \\
\text { transformerless designs and innovative topologies are yielding higher efficiencies, with } \\
\text { one model claiming 98\%. }\end{array}$ \\
\hline Lower Cost & $\begin{array}{l}\text { - A price target of around \$0.2-0.3/W by 2020 has been set for inverters, which represents } \\
\text { a reduction of 50-75\% from current levels. This is most likely to be achieved through } \\
\text { increased production volumes and learning-curve improvements. }\end{array}$ \\
\hline Better Reliability & $\begin{array}{l}\text { - Inverter MTBF is now in the 5- to 10-year range. Ideally, inverters would last as long as } \\
\text { other PV system components (i.e. 25 years), but many question whether such } \\
\text { improvements will ever be achievable at a reasonable cost. In the near- to medium-term, } \\
\text { an MTBF of }>10 \text { years is likely to be achievable through improving quality control, better } \\
\text { heat dissipation, and reducing complexity. }\end{array}$ \\
\hline $\begin{array}{l}\text { Advanced } \\
\text { Communication }\end{array}$ & $\begin{array}{l}\text { - Today, inverters can record and relay information using manufacturer specific } \\
\text { protocols. Next-generation units should use a universal communication standard to } \\
\text { relay more comprehensive system information, enabling advanced diagnostic features } \\
\text { and communication with the utility to support grid stability. }\end{array}$ \\
\hline DG Inverter & $\begin{array}{l}\text { An inverter that can convert DC input from various DG sources (fuel cells, PV, small } \\
\text { wind) will benefit from economies of scale, and new technology (e.g., SiC), resulting in } \\
\text { cheaper, more reliable products for many DG applications. }\end{array}$ \\
\hline
\end{tabular}

1. SMA Sunny Mini Central 8000TL 


\section{Future Performance Summary}

\section{Achieving the targeted improvements of lower cost and higher reliability for inverters is not a foregone conclusion for the industry.}

- Based on learning-curve forecasts, the targeted cost reductions for 2020 will not be achieved with current market growth and learning-rate levels.

- Significant uncertainty exists around the potential for future market growth to exceed current levels for an extended period of time.

- Additional cost reductions will require an acceleration of learning effects.

$>$ Inverter prices have been dropping by about $10 \%$ with every doubling of cumulative production, compared to $20 \%$ for PV modules.

- Reliability and life issues for inverters have the potential to damage the reputation of the industry and long-term adoption of PV.

- Because of market demands, manufacturers today are focused on lowering first-cost over improving reliability.

- Reliability and life improvements may not be achieved with consistency across the industry.

In order to increase the probability of achieving the goals of industry, which are necessary for the PV market to become sustainable over the long term, ongoing government support for inverter R\&D is likely to be necessary. 


\begin{tabular}{|c|l|}
\hline 1 & Executive Summary \\
\hline 2 & Introduction \\
\hline 3 & Historical Perspective \\
\hline 4 & Future Performance and Cost Estimates \\
\hline 5 & Challenges for Achieving Future Targets \\
\hline 6 & Addressing the Challenges \\
\hline 7 & Suggested Role for Government \\
\hline
\end{tabular}




\section{The PV inverter industry faces some significant challenges to achieving its longer-term targets for cost and performance improvements.}

- Research shows that inverters have a slower learning curve than the PV module industry, which implies that cost and performance improvements for inverters will lag behind PV modules.

- Historical data shows that inverter costs have been falling approximately 5-10\% a year since 1999 .

- We anticipate this cost reduction curve to continue into the future, assuming the industry grows as forecast.

- Manufacturers generally feel that designing inverters for longer than 15 years is not practical and, in general, is not necessary. Most manufacturers say that the more important issue for consumers is lower first-cost.

- A 20-year MTBF is viewed as not possible and may not be an appropriate target.

- Inconsistent national and state regulatory standards have hurt PV inverter manufacturers' ability to grow in the past, limiting many to focus on regional markets.

- This issue is gradually improving; but, in the United States, differences in requirements for states will likely continue to impede cost benefits associated with larger market volumes, at least for the next few years.

- On the other hand, given their small size and relatively low level of sophistication, PV inverter manufacturers may benefit tremendously from small improvements to design and manufacturing (e.g. low-hanging fruit for cost and performance improvements).

- Improvement in components (such as capacitors), the trend to high-frequency transformers, or transformerless designs are examples of opportunities that will contribute to cost and performance improvements. 


\section{Many of the challenges for PV inverters are a result of low-volume manufacturing and an inconsistent regulatory environment.}

\begin{tabular}{|l|l|}
\hline Manufacturing & 1. Inadequate product-improvement processes \\
& 2. Lack of training \\
& 3. Products rushed to market too quickly \\
& 4. Lack of good quality-control processes \\
& 5. Lack of investment in sophisticated testing and manufacturing equipment \\
& 6. Components purchased in small quantities \\
\hline Design/Technology & 7. Advanced semiconductor devices for switching needed (e.g. SiC devices) \\
& 8. Need to improve efficiency \\
& 9. Limited experimentation with alternative inverter topologies \\
& 10. Capacitors available on the market are not well-suited to PV inverter applications \\
& 11. Lack of sophistication in inverter designs (e.g. leveraging synergistic applications) \\
\hline Regulatory & 12. Regulations differ across PV markets \\
& 13. Regulatory complexity generally increases cost \\
& 14. U.S. grid-interconnection regulations are a heavy burden on inverter manufacturers \\
& 15. U.S. requirements for PV installation increase costs substantially \\
& 16. Utility resistance to ungrounded systems \\
\hline Policy & 17. Few states have adequate incentives to promote PV market growth \\
18. Changing policies hamper long-term investment decisions
\end{tabular}




\section{Many manufacturers are small startups that lack the internal processes needed for quality control of product development and manufacturing.}

\begin{tabular}{|c|c|}
\hline $\begin{array}{l}\text { 1. Inadequate } \\
\text { product } \\
\text { improvement } \\
\text { processes }\end{array}$ & $\begin{array}{l}\text { Internal processes that provide the discipline, resources, and commitment } \\
\text { needed for continuous product improvement are lacking among many small } \\
\text { inverter manufacturers. }\end{array}$ \\
\hline $\begin{array}{l}\text { 2. Lack of } \\
\text { training }\end{array}$ & $\begin{array}{l}\text { Inverter manufacturers typically have a small workforce, where employees are } \\
\text { asked to perform several different tasks, often without adequate training. }\end{array}$ \\
\hline $\begin{array}{l}\text { 3. Products } \\
\text { rushed to } \\
\text { market }\end{array}$ & $\begin{array}{l}\text { The pressure to ship as soon as possible leads manufacturers to produce poorly } \\
\text { written and insufficient documentation, leading to low installer/customer } \\
\text { satisfaction and expensive customer support. }\end{array}$ \\
\hline $\begin{array}{l}\text { 4. Lack of good } \\
\text { quality- } \\
\text { control } \\
\text { processes }\end{array}$ & $\begin{array}{l}\text { - Due to limited resources, inverter manufacturers compromise quality control: } \\
\text { - Inspections that can identify problems early in the manufacturing process are } \\
\text { not carried out properly. } \\
\text { - Proven methods such as "Highly Accelerated Life Tests" (HALT) are often } \\
\text { overlooked or not used. } \\
\text { - "Failure" documentation is inadequate or nonexistent. Inverter } \\
\text { manufacturers typically have little information on failures of their units in the } \\
\text { field or during testing, making it difficult to identify problem trends and take } \\
\text { corrective action. } \\
\text { Inadequate quality control leads to reliability problems and ultimately imposes } \\
\text { additional costs on inverter manufacturers. }\end{array}$ \\
\hline
\end{tabular}




\section{Low production volumes make it impossible for manufacturers to take advantage of mass-production technologies and volume discounts.}

\begin{tabular}{|c|c|}
\hline $\begin{array}{l}\text { 5. Lack of } \\
\text { investment in } \\
\text { sophisticated } \\
\text { testing and } \\
\text { manufacturing } \\
\text { equipment }\end{array}$ & $\begin{array}{l}\text { - Most inverter manufacturers are small companies } \\
\text { - They cannot afford expensive testing equipment based on their modest sales } \\
\text { volume. } \\
\text { - Low production volumes cannot justify the investment needed for an } \\
\text { automated production line, and they do not have the needed expertise. } \\
\text { Inverter manufacturers cannot make investments that would greatly improve } \\
\text { product quality, because their sales volumes don't currently justify it. Proven } \\
\text { methods to detect design flaws such as "Highly Accelerated Life Tests" (HALT) are } \\
\text { not used. }\end{array}$ \\
\hline $\begin{array}{l}\text { 6. Components } \\
\text { purchased in } \\
\text { small quantities }\end{array}$ & $\begin{array}{l}\text { - Most inverter manufacturers purchase components in small quantities, due to } \\
\text { modest sales volume: } \\
\text { - They cannot benefit from discounts offered on large orders and better supply- } \\
\text { chain management } \\
\text { - With each new order for a given component, inverter manufacturers often } \\
\text { purchase from different suppliers, depending on where they can find the best } \\
\text { price. This results in wide component variations and problems with the final } \\
\text { product. } \\
\text { - Inverter manufacturers typically do not audit their suppliers for quality control. } \\
\text { Purchasing components in small quantities leads to higher cost and lower quality - } \\
\text { and impacts reliability. }\end{array}$ \\
\hline
\end{tabular}




\section{Components available on the market today do not adequately meet the technical requirements of the inverters.}
7. Advanced semiconductor devices needed for switching. (e.g. SiC devices)

- The various switching devices used in inverters to convert DC to AC current are another weak point for inverter reliability.

- There are technologies (e.g. SiC switches and integrated circuits) that show promise for better performance, but inverter manufacturers have little weight in influencing the direction of $R \& D$ and most have limited internal $R \& D$ capabilities in this area.

D Switch reliability is currently inadequate for PV inverters and is a source of heat generation. New developments (such as $\mathrm{SiC}$ ) are a power electronics/semiconductor industry issue, and inverter manufacturers will have little influence in directing research in this industry. 


\section{Lack of resources and design experience hampers inverter product design and development improvements.}

\begin{tabular}{|c|c|}
\hline $\begin{array}{l}\text { 8. Need to improve } \\
\text { efficiency and the } \\
\text { standards for } \\
\text { ratings }^{1}\end{array}$ & $\begin{array}{l}\text { - Maximum efficiencies are typically near } 95 \% \text { for U.S. inverters, but manufacturers } \\
\text { do not have consistent methods for rating inverters and can choose any point over } \\
\text { the load curve for quoting the rating. } \\
\text { - Consumers do not have an easy way to compare inverters based on efficiency. } \\
\text { Certification processes could provide standard test methods for rating efficiency. } \\
\text { Design improvements and elimination of transformers could improve efficiencies by } \\
2 \% \text { or more. }\end{array}$ \\
\hline $\begin{array}{l}\text { 9. Limited } \\
\text { experimentation } \\
\text { with inverter } \\
\text { topologies }\end{array}$ & $\begin{array}{l}\text { - Converting DC to AC current can be done } \\
\text { using a variety of approaches. The various } \\
\text { designs that inverter manufacturers } \\
\text { incorporate in their inverters to accomplish } \\
\text { this task are known as "topologies." } \\
\text { - Various topologies yield different inverter } \\
\text { performances in terms of reliability, efficiency, } \\
\text { and cost. While there is generally a trade-off } \\
\text { between these three objectives, some } \\
\text { topologies are simply better than others and } \\
\text { can improve inverters in every respect. } \\
\text { Inverter manufacturers do not have the resources to experiment with topologies } \\
\text { extensively, so potential inverter improvements may be lost. }\end{array}$ \\
\hline
\end{tabular}

1. The CEC recently adopted and is using a major portion of Sandia's Test Protocol for Certification of Inverters. Several states are now accepting California's published numbers. Still, more needs to be done for features such as MPPT. 


\section{Component limitations and lack of design experience hampers inverter product design and development.}

10. Capacitors available on the market not suited for PV inverter applications.
- Capacitors are often cited as the most severe reliability problem for inverters. They are extremely sensitive to temperature (electrolytic capacitors), and one manufacturer reports that an increase of even $10^{\circ} \mathrm{C}$ can halve capacitor lifetime (Heliotronics, President, January 2005).

- There are capacitor technologies that show promise for better performance in PV inverters, but R\&D in the capacitor industry is limited

- The capacitor industry is not responsive to PV inverter needs, because PV inverters account for a small fraction of capacitors sold.

- Capacitor reliability is currently inadequate for PV inverters, and there is little that inverter manufacturers can do to influence the capacitor industry other than design around the problem, which impacts cost.

11. Lack of sophistication in inverter designs
- Engineers from other, more mature industries where power electronics are used have commented that inverter designs are unsophisticated and could often be improved with some fairly easy fixes (Sun Power, North American Manager, June 2005).

- Many PV inverter manufacturers lack knowledge or broader experience in power electronics design. 


\section{Lack of an international standard creates regional markets for inverters. In the U.S., regulations are particularly burdensome for manufacturers.}

\begin{tabular}{|l|l|}
\hline $\begin{array}{l}\text { 12. Regulations } \\
\text { differ across PV } \\
\text { markets }\end{array}$ & $\begin{array}{l}\text { - Regulations for grid-connected PV inverters vary across countries. In Europe, } \\
\text { requirements across some countries (e.g. Germany, the Netherlands, } \\
\text { Switzerland) vary only slightly, and manufacturers are able to use the same } \\
\text { inverter models to reach these markets. }\end{array}$ \\
$\begin{array}{l}\text { - Requirements are most stringent in the United States. International } \\
\text { manufacturers who want to serve this market need to design models } \\
\text { specifically for the United States in order to meet regulations. }\end{array}$ \\
$\begin{array}{l}\text { This lack of uniformity creates regional markets, making it extremely difficult } \\
\text { for manufacturers to create a global product (as with modules). By preventing } \\
\text { standardization across markets, potential economies of scale are lost. }\end{array}$ \\
$\begin{array}{l}\text { 13. Regulatory } \\
\text { complexity } \\
\text { increases cost }\end{array}$ & $\begin{array}{l}\text { Regulatory differences between states or countries require product } \\
\text { modifications and specialization, which increases costs for manufacturers. }\end{array}$ \\
& $\begin{array}{l}\text { Different safety requirements, interconnection, or testing requirements } \\
\text { increase the cost for manufacturers for selling their products in different } \\
\text { markets. }\end{array}$ \\
$\begin{array}{l}\text { Product lines vary by market, and some companies choose to focus on specific } \\
\text { states and not others. These issues lead to higher prices in all markets. }\end{array}$ \\
\hline
\end{tabular}




\section{Requirements for grid connection vary significantly in spite of UL and IEEE standards that are expensive for manufacturers to meet.}
14. U.S. grid- connection regulations are a heavy burden on inverter manufacturers

- U.S. manufacturers face confusing regulations.

- In 2005, UL 1741 and IEEE 1547 have apparently been consolidated in a way that should help resolve some of the confusion around compliance with these two standards. Ongoing changes to the requirements of these standards is likely to continue to create challenges for manufacturers.

- Acquiring the UL 1741 standard costs nearly $\$ 100 \mathrm{~K}$, a substantial amount for small players; and modifications typically require additional testing, which is a barrier to making improvements.

- Utilities can also adopt their own standards, adding to the complexity.

- UL standards are a damper on innovation, because product improvements require new testing for modest changes to designs. Utilities and local government can also require their own standards, which increases cost. 


\section{Inverter and installation costs are significantly higher in the U.S., driven by complex requirements and local codes that still requiring grounding.}

\begin{tabular}{|c|c|}
\hline $\begin{array}{l}\text { 5. U.S. } \\
\text { requirements for } \\
\text { PV installations } \\
\text { increase costs } \\
\text { substantially }\end{array}$ & $\begin{array}{l}\text { - Manufacturers who sell PV inverters in European markets - and in the United } \\
\text { States - report that installation costs are substantially higher in the United States. } \\
\text { - The installed cost of a } 5 \mathrm{~kW} \text { system is about } € 4.2-5.0 / \mathrm{W} \text { in Germany, as } \\
\text { opposed to } \$ 6.50-9.00 / \mathrm{W} \text { in the United States (Head of } \\
\text { Solar Electronics Division, Fronius, January } 2005) \\
\text { - The cost of installation of a } 5 \mathrm{~kW} \text { system is about } € 700 / \mathrm{kW}(\$ 833 / \mathrm{kW}) \text { in } \\
\text { Germany, as opposed to } \$ 1,400 / \mathrm{kW} \text { in the U.S. } \\
\text { - One of the areas of higher cost in the United States is related to the requirements } \\
\text { for externally accessible AC disconnects and conduits for DC cabling. } \\
\text { Roughly speaking, installation costs for PV in the United States are nearly twice } \\
\text { that of Germany. }\end{array}$ \\
\hline $\begin{array}{l}\text { 16. Utility and local } \\
\text { resistance to } \\
\text { ungrounded } \\
\text { systems }\end{array}$ & $\begin{array}{l}\text { - Ungrounded PV array installations are allowed by the } 2005 \text { National Electric } \\
\text { Code, which means that transformerless inverters could now be used in the U.S. } \\
\text { - However, it is expected that these systems may be difficult for U.S. inspectors } \\
\text { and regulators to accept without substantial additional work on local codes and } \\
\text { standards. } \\
\text { inverter improvements: higher efficiency, lower weight, and lower cost. }\end{array}$ \\
\hline
\end{tabular}




\section{PV market growth is restricted to a handful of states, limiting prospects for inverter manufacturers and hampering investment.}

\begin{tabular}{|l|l|}
\hline $\begin{array}{l}\text { 17. Few states have } \\
\text { adequate } \\
\text { incentives to } \\
\text { promote PV } \\
\text { market growth }\end{array}$ & $\begin{array}{l}\text { - Several states have very good incentives for PV (e.g. Calif., N.Y., N.J.), but many } \\
\text { states in areas such the Southeast have no buy-down programs or other } \\
\text { incentives to stimulate installations of PV. }\end{array}$ \\
$\begin{array}{l}\text { O Where incentives are inadequate, the PV market will see very limited growth, } \\
\text { and potential economies of scale in the United States for inverter manufacturers } \\
\text { will remain untapped. }\end{array}$ \\
$\begin{array}{l}\text { 18. Changing } \\
\text { policies hamper } \\
\text { investment }\end{array}$ & $\begin{array}{l}\text { - Major investment on the part of inverter manufacturers depends on a high level } \\
\text { of confidence in future income streams. } \\
\text { - Uncertain or changing incentives for PV create the wrong kind of incentives for } \\
\text { manufacturers, who respond by putting their product on the market as quickly } \\
\text { as possible, without investing in lengthy product development or sophisticated } \\
\text { assembly and testing equipment. } \\
\text { O Without stable PV support policies, inverter manufacturers will be unable to } \\
\text { make substantial investments to improve their product. }\end{array}$ \\
\hline
\end{tabular}




\section{The majority of challenges faced by PV inverter manufacturers can be traced back to low production volumes.}

\begin{tabular}{|l|l|}
\hline $\begin{array}{l}\text { "Economies of scale will create a } \\
\text { downward pressure on PV inverter } \\
\text { costs." }\end{array}$ & $\begin{array}{l}\text { "Sales volume in each market } \\
\text { will drive the price of inverters." } \\
\begin{array}{l}\text { Sun Power, North American Manager, } \\
\text { June } 2005\end{array}\end{array}$ \\
\hline $\begin{array}{l}\text { "Our costs have gone down 50\% due } \\
\text { to volume. Volume is the only cost } \\
\text { driver." }\end{array}$ & $\begin{array}{l}\text { "SMA believes that cost } \\
\text { reductions will be a combination } \\
\text { of new designs, new topologies, } \\
\text { less components, and higher } \\
\text { quantities." } \\
\text { SMA, Head of Solar Division, June } 2005\end{array}$ \\
\hline
\end{tabular}

- There does not a appear to be a "silver bullet" technology on the horizon that could cause a major drop in inverter cost.

- The industry anticipates incremental cost and performance improvements for the foreseeable future. 
The PV inverter supplier base is composed of a few big companies with considerable resources and many smaller players (others) who are more likely to benefit from government programs.
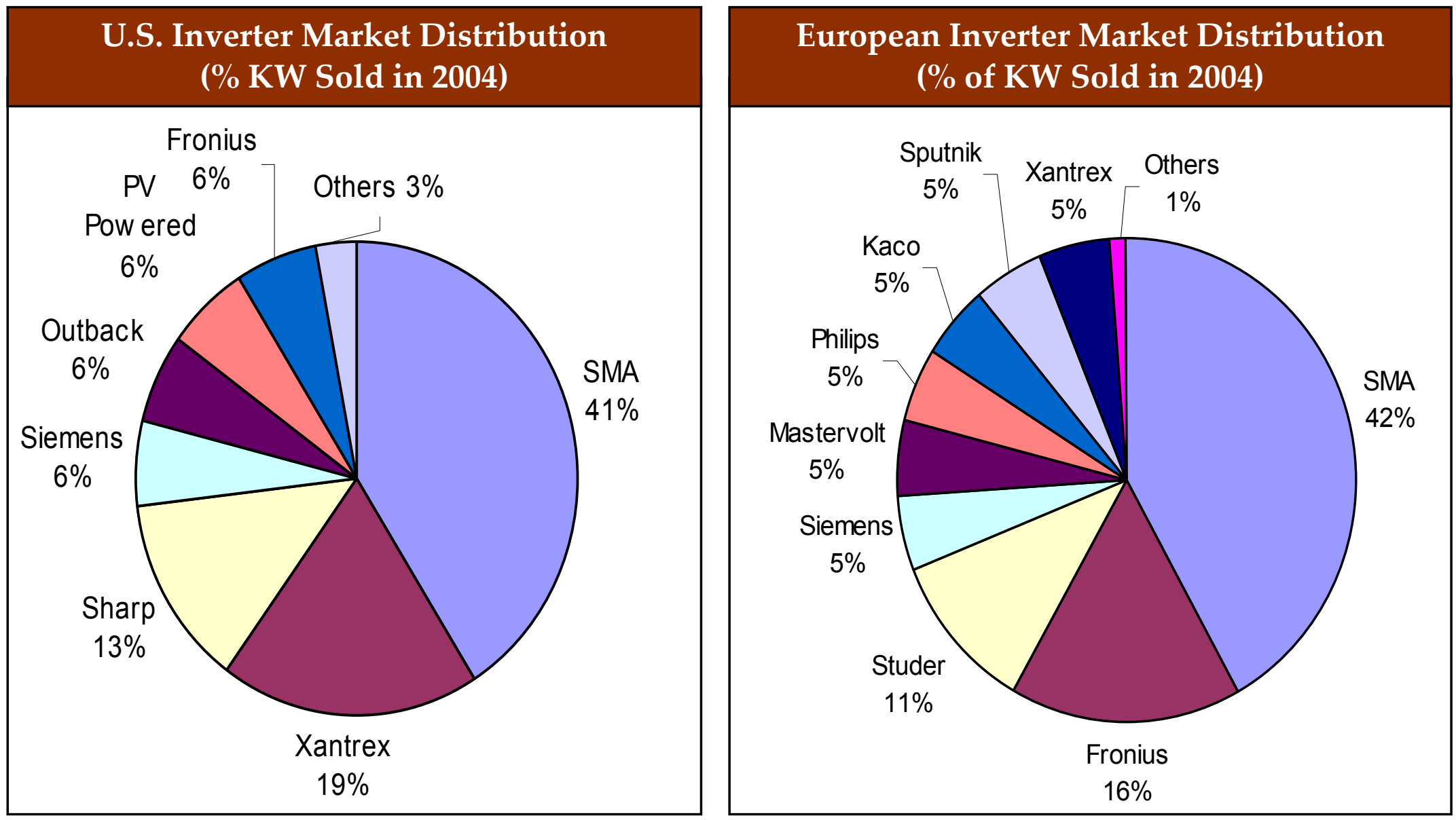

Source: Navigant Consulting Analysis, August 2005 


\section{NCI's assessment is that there is an important role for government in the support of PV inverter improvements for the next several years.}

- In general, larger companies in the PV inverter business view the role of government in providing assistance (via programs to reduce cost and increase reliability) as being less critical to their success and the long-term future of the industry.

- Most larger companies NCI spoke to believe that increasing sales volume is the single largest factor that will lead to lower cost and higher reliability for PV inverters.

- Despite the views of larger companies, introducing a new inverter product has proven to be a risky venture for some large companies. For example:

- Xantrex experienced significant problems with their early PV inverters and ended up losing market share to new European market entrants.

- Philips entered the PV inverter market in Europe, only to exit a few years later after experiencing significant technical problems with their first product.

- The PV market will be in a critical growth phase during the next 5-10 years, continuing to require significant policy and market support to achieve the overall cost and performance required for a sustainable market.

- If small manufacturers have more difficulty meeting the reliability requirements of the market and cannot afford to provide adequate after-sales service, it could hurt the PV industry as a whole (inadequately performing inverters will hurt the industry).

- While some consolidation in the inverter business should be expected, the benefits of competition and innovation provided by the smaller companies are likely to be important to the industry at its current, early stage of development. 


\begin{tabular}{|c|l|}
\hline 1 & Executive Summary \\
\hline 2 & Introduction \\
\hline 3 & Historical Perspective \\
\hline 4 & Future Performance and Cost Estimates \\
\hline 5 & Challenges for Achieving Future Targets \\
\hline 6 & Addressing the Challenges \\
\hline 7 & Suggested Role for Government \\
\hline
\end{tabular}




\section{Apart from influencing standards and increasing market volume, inverter gains will come from addressing design/manufacturing challenges.}

\begin{tabular}{|c|c|c|}
\hline & Challenge & Addressing the Challenge (Industry Need) \\
\hline $\begin{array}{l}\text { Manufacturing } \\
\text { /Testing }\end{array}$ & $\begin{array}{l}\text { 1. Inadequate product improvement processes } \\
\text { 2. Lack of training } \\
\text { 3. Products rushed to market too quickly } \\
\text { 4. Lack of good quality-control processes } \\
\text { 5. Lack of investment in sophisticated testing and } \\
\text { manufacturing equipment } \\
\text { 6. Components purchased in small quantities }\end{array}$ & $\begin{array}{l}\text { - Assistance for inverter manufacturers with information and } \\
\text { process improvement techniques from other industries } \\
\text { - Better understanding of failure causes } \\
\text { - Training and support in quality management } \\
\text { - Standard testing methods to measure and quote efficiency } \\
\text { - Assistance with HALT and HASS methods and techniques for } \\
\text { lowering risk associated with new product introduction } \\
\text { - Consistent information on component design characteristics }\end{array}$ \\
\hline $\begin{array}{l}\text { Technology/ } \\
\text { Design }\end{array}$ & $\begin{array}{l}\text { 7. Advanced semiconductor devices for switching needed } \\
\text { (e.g. SiC diodes) } \\
\text { 8. Need to improve efficiency } \\
\text { 9. Limited experimentation with alternative inverter } \\
\text { topologies } \\
\text { 10. Capacitors available on the market are not well-suited to } \\
\text { PV inverter applications } \\
\text { 11. Lack of sophistication in inverter designs }\end{array}$ & $\begin{array}{l}\text { - Development of advanced switching, capacitor, and other } \\
\text { component technologies for PV and DER inverters } \\
\text { - Modeling tools for experimentation with alternative topologies, } \\
\text { thermal management techniques, and new designs } \\
\text { - Support design of alternative inverter topologies to simplify and } \\
\text { reduce cost of inverters } \\
\text { - Modular designs that would allow lower-cost, interchangeable } \\
\text { components for multiple applications }\end{array}$ \\
\hline Regulatory & $\begin{array}{l}\text { 12. Regulations differ across PV markets } \\
\text { 13. Regulatory complexity generally increases cost } \\
\text { 14. U.S. grid-interconnection regulations are a heavy burden } \\
\text { on inverter manufacturers } \\
\text { 15. U.S. requirements for PV installation increase costs } \\
\text { substantially } \\
\text { 16. Utility resistance to ungrounded systems }\end{array}$ & $\begin{array}{l}\text { - Development of appropriate standards across the industry } \\
\text { - Harmonization of regulatory requirements } \\
\text { - Simplification and standardization of interconnection } \\
\text { requirements } \\
\text { - Studies and assessments of options for ungrounded designs, } \\
\text { safety issues, and a broader understanding of the implications }\end{array}$ \\
\hline Policy & $\begin{array}{l}\text { 17. Few states have adequate incentives to promote PV } \\
\text { market growth } \\
\text { 18. Changing policies hamper investment }\end{array}$ & $\begin{array}{l}\text { - Long-term programs for national incentives for PV } \\
\text { - Policy that supports the PV industry broadly, which will also } \\
\text { support the inverter industry }\end{array}$ \\
\hline
\end{tabular}




\section{Some manufacturers can benefit from assistance in performing some of the tasks they cannot do, due to their small size and limited resources.}

\begin{tabular}{|c|c|}
\hline \multicolumn{2}{|r|}{ Inverter Manufacturing and Testing } \\
\hline $\begin{array}{l}\text { Process } \\
\text { Improvement } \\
\text { Techniques and } \\
\text { Training }\end{array}$ & $\begin{array}{l}\text { - General support in understanding process-improvement techniques from } \\
\text { other industries (semiconductors, electronics, etc...) to reduce } \\
\text { manufacturing cost. } \\
\text { - Training and support in quality-control techniques used in other high- } \\
\text { volume manufacturing industries (semiconductors, electronics). }\end{array}$ \\
\hline $\begin{array}{l}\text { Failure } \\
\text { Documentation }\end{array}$ & $\begin{array}{l}\text { Development of a database to document inverter failures in the field. } \\
\text { Analysis of this database would allow inverter manufacturers to identify } \\
\text { failure modes and correct their designs to improve reliability. }\end{array}$ \\
\hline $\begin{array}{l}\text { Testing Support - } \\
\text { Performance, HALT } \\
\text { and HASS }\end{array}$ & $\begin{array}{l}\text { - Assist manufacturers by providing support for testing inverters, e.g. IR } \\
\text { imaging for thermal management testing, highly accelerated life tests to } \\
\text { identify weaknesses, HALT and HASS, etc. } \\
\text { - Assistance in developing methods and protocols for testing and } \\
\text { specifying inverter efficiency. }\end{array}$ \\
\hline $\begin{array}{l}\text { Component Testing } \\
\text { and Documentation }\end{array}$ & $\begin{array}{l}\text { Test components (e.g. capacitors) to measure their characteristics and rate } \\
\text { their performance - and document the results. There is a great degree of } \\
\text { variation between components available on the market, and this } \\
\text { documentation would allow inverter manufacturers to select the best } \\
\text { available components to incorporate into their products. }\end{array}$ \\
\hline
\end{tabular}




\section{Addressing the Challenges Assistance with Technology and Design}

\section{Many potential inverter technology and design improvements have been identified.}

\begin{tabular}{|l|l|}
\hline \multicolumn{2}{|c|}{ New Inverter Technology and Design (1 of 3) } \\
\hline DER inverters ${ }^{1}$ & $\begin{array}{l}\text { - Inverters used for a variety of DER applications could be produced in greater } \\
\text { quantities, allowing manufacturers to benefit from economies of scale. } \\
\text { - The challenge for PV inverter manufacturers is to understand the } \\
\text { requirements of other DER applications and design inverters suitable for } \\
\text { other applications. } \\
\text { Note: Sustainable Energy Technologies has already designed a PV inverter } \\
\text { that relies on essentially the same design as its fuel cell inverter. }\end{array}$ \\
\hline Modeling & $\begin{array}{l}\text { - Develop and provide modeling tools to enable manufacturers to explore } \\
\text { various inverter designs. }\end{array}$ \\
\hline $\begin{array}{l}\text { Innovative } \\
\text { Topolop models for environmental conditions and operational requirements } \\
\text { to help inverter designers understand operational requirements }\end{array}$ \\
\hline $\begin{array}{l}\text { Installation and } \\
\text { Connection Features }\end{array}$ & $\begin{array}{l}\text { Innovative topologies can reduce capacitor requirements and alleviate } \\
\text { thermal management problems that lead to premature failure of internal } \\
\text { components - but developing new topologies takes time and money. } \\
\text { needed to simplify, standardize, and improve inverter connectors. }\end{array}$ \\
\hline
\end{tabular}

1. Inverters that can be used for multiple distributed generation energy sources are referred to as distributed generation (DG) or distributed energy resource (DER) inverters. 


\section{Addressing the Challenges Assistance with Technology and Design}

\section{Many potential inverter technology improvements have been identified (continued).}

\begin{tabular}{|l|l|}
\hline \multicolumn{2}{|c|}{ New Inverter Technology and Design (2 of 3) } \\
\hline Circuit Integration & $\begin{array}{l}\text { - Interconnections between internal inverter components are a weak point } \\
\text { for reliability. Integration of functions within imbedded circuits reduces } \\
\text { the number of interconnections. R\&D is needed to develop this concept } \\
\text { and bring it to maturity. }\end{array}$ \\
\hline $\begin{array}{l}\text { Thermal } \\
\text { Management }\end{array}$ & $\begin{array}{l}\text { - Thermal management is a major reliability issue for inverters, because } \\
\text { many components are highly sensitive to temperature. Better thermal } \\
\text { modeling tools are needed to allow manufacturers to research innovative } \\
\text { thermal management strategies. }\end{array}$ \\
\hline Modular Design & $\begin{array}{l}\text { - Modular construction of inverters would reduce costs by standardizing } \\
\text { internal functional elements of inverters. This is an interesting concept } \\
\text { that could benefit from further study. } \\
\text { Note: Modularity may cause listing difficulties with UL. }\end{array}$ \\
\hline $\begin{array}{l}\text { Replaceable } \\
\text { Capacitors }\end{array}$ & $\begin{array}{l}\text { To cope with the limited life of capacitors, it has been suggested that } \\
\text { inverters be designed such that capacitors may be easily replaced. The } \\
\text { cost-effectiveness of this approach needs to be assessed. }\end{array}$ \\
\hline
\end{tabular}




\section{Addressing the Challenges Advanced Inverter Components}

\section{Inverter manufacturers need cheaper, more reliable components to make less expensive, more reliable inverters.}

\begin{tabular}{|l|l|}
\hline \multicolumn{2}{|c|}{ New Inverter Technology and Design (3 of 3) - Advanced Components } \\
\hline Capacitors & $\begin{array}{l}\text { - Inverter manufacturers frequently state that the capacitors available today } \\
\text { are inadequate. Specifically, manufacturers need twice the life and half the } \\
\text { cost of today's capacitors. } \\
\text { - R\&D is needed to develop improved capacitors, but the PV inverter } \\
\text { industry does not have the resources to carry out this R\&D or influence } \\
\text { the capacitor industry, due to the relatively low volumes as compared to } \\
\text { other electronics applications. }\end{array}$ \\
\hline Switches & $\begin{array}{l}\text { Switches based on SiC hold the promise of better performance: They can } \\
\text { tolerate higher temperatures, can handle very high voltages, they have } \\
\text { low resistance, and can operate at high frequency - which translates into } \\
\text { inverter improvements in weight, size, cost, reliability, and efficiency. } \\
\text { - Commercial applications of SiC are currently limited, due to product } \\
\text { immaturity and high cost. }\end{array}$ \\
\hline $\begin{array}{l}\text { Transient Surge } \\
\text { Devices }\end{array}$ & Research in TSDs is currently minimal, but improvements are needed for \\
both DC and AC circuits.
\end{tabular}




\section{Manufacturers need regulatory standards that are clear and uniform across markets - and not constantly changing.}

\begin{tabular}{|l|l|}
\hline \multicolumn{2}{|c|}{ Regulatory Assistance } \\
\hline Harmonization & $\begin{array}{l}\text { - Push for harmonization of the various standards that regulate grid- } \\
\text { connection of PV inverters and other DER. }\end{array}$ \\
\hline $\begin{array}{l}\text { Reduce Burden on } \\
\text { Manufacturers }\end{array}$ & $\begin{array}{l}\text { - Increase participation of manufacturers in development of standards by } \\
\text { subsidizing cost of attending meetings. } \\
\text { - Subsidize cost of acquiring standards. }\end{array}$ \\
\hline $\begin{array}{l}\text { Acceptance of } \\
\text { Ungrounded Arrays }\end{array}$ & $\begin{array}{l}\text { - Address utility misgivings regarding safety concerns on ungrounded PV } \\
\text { arrays and transformerless inverters. Experience from Japan and Europe } \\
\text { needs to be transferred to the United States. }\end{array}$ \\
\hline Standard & $\begin{array}{l}\text { A standard for communicating DG system information is needed for: } \\
\text { 1. Remote monitoring and system diagnostics of inverters using a single } \\
\text { software platform. } \\
\text { 2. Efficient communication between DG inverters and the utility grid to } \\
\text { minimize DG interruptions and improve grid stability. }\end{array}$ \\
\hline $\begin{array}{l}\text { Standard Metrics for } \\
\text { Inverter } \\
\text { Performance }\end{array}$ & $\begin{array}{l}\text { - There are no established methods for rating inverter performance that } \\
\text { consumers and installers can use to compare inverters (e.g. efficiency can } \\
\text { be reported in any number of ways). This would promote transparency in } \\
\text { the market and favor better inverters while rooting out laggards. }{ }^{1}\end{array}$ \\
\hline
\end{tabular}

1. The CEC recently adopted and is using a major portion of Sandia's Test Protocol for Certification of Inverters. 


\section{Addressing the Challenges Assistance with PV Policy}

\section{One of the most important challenges facing the industry is the need for long-term, consistent policy to support market development on a national basis.}

\section{Policy Assistance}

Long-Term,

Consistent PV

Policy Support
- The U.S. policies for support of PV are currently divided between federal, state, and local programs. While some programs are year-to-year, others are multiyear programs to meet PV installation goals.

- Long-term support to programs to build the market for PV consistently, without stops and starts, will help the industry maintain and grow sales volumes in a way that will allow continual cost reduction as well as reliability and performance improvement. Because market volume is the most important driver in achieving goals of the industry, this area is one of the most critical to the industry. These policies are important for PV as a whole, not just for inverters. 


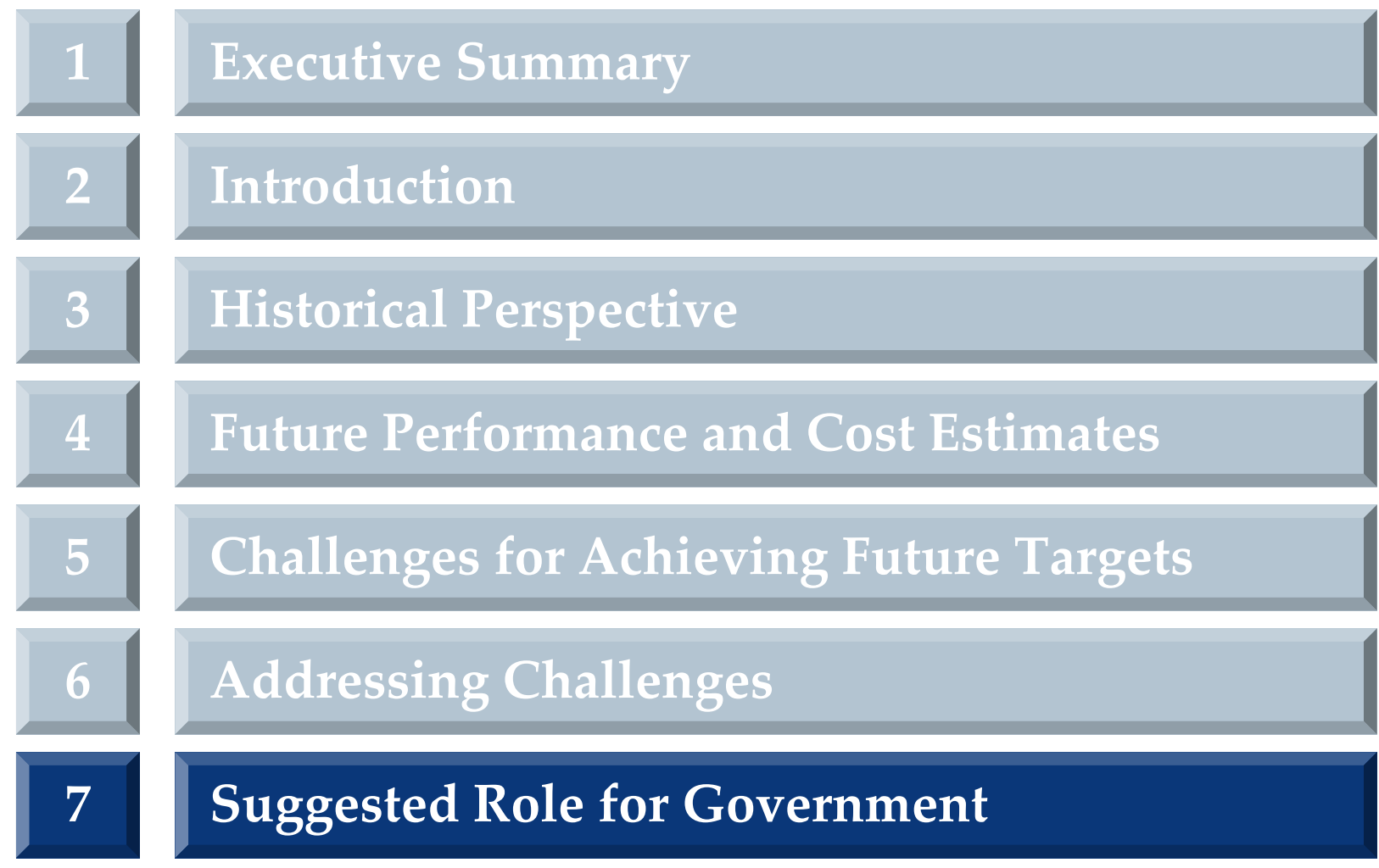




\section{Suggested Role for Government Overview}

\section{Long-term cost reduction and performance improvements will benefit greatly from the ongoing support of additional government programs.}

- Inverter testing at Sandia National Labs is extremely valuable to the industry, and continued support of development of testing protocols is important to the industry.

- Documentation of failure analysis in the industry is not conducted uniformly. A possible role for government would be in collecting and documenting inverter failures to share with the industry.

- Modeling tools would be helpful to manufacturers, but developing accurate models is challenging. An assessment of issues and needs related to modeling would be appropriate before embarking on new modeling efforts.

- The HRII program is generally considered to have been successful. Follow-on public-private $R \& D$ partnerships such as this should receive government support.

- Cost and efficiency benefits of tranformerless inverters are understood. Studies on the pros and cons of tranformerless inverters as a means of educating inspectors and regulators would be beneficial.

- Analysis of the interaction of the various federal, state, and municipal support programs will be increasingly important to future industry growth needed for long-term success. 


\section{Suggested Role for Government Overview}

\section{Several issues identified are common to all DER inverters and could be addressed as part of crosscutting research programs.}

- Comprehensive information on inverter components (capacitors, electrical connectors, power semiconductors, etc.) and options would assist manufacturers in identifying the best products.

- Innovative inverter topologies have been suggested to provide many benefits. A role for government may be to support experimental topologies as a means of advancing the industry.

- Manufacturers would benefit from understanding the costs and benefits of HALT and HASS testing programs. Government could assist by providing general guidelines and experience from other industries.

- Several other areas identified for PV inverters may also have broader benefit to DER inverters, such as modeling and HALT and HASS testing protocols; but more specific programs for PV are likely to be required. 


\section{Government's most important role will continue to be in providing studies and information to facilitate design and product improvements.}

\begin{tabular}{|c|c|c|}
\hline & Addressing the Challenge (Industry Need) & Role for Government \\
\hline $\begin{array}{l}\text { Manufacturing } \\
\text { /Testing }\end{array}$ & $\begin{array}{l}\text { - Assistance for inverter manufacturers with information and } \\
\text { process improvement techniques from other industries } \\
\text { - Better understanding of failure causes } \\
\text { - Training and support in quality management } \\
\text { - Standard testing methods to measure and quote efficiency } \\
\text { - Assistance with HALT and HASS methods and techniques for } \\
\text { lowering risk associated with new product introduction } \\
\text { - Consistent information on component design characteristics }\end{array}$ & $\begin{array}{l}\text { - Government facilities can provide manufacturers with top- } \\
\text { class inverter testing, as well as testing methodologies for } \\
\text { establishing ratings and efficiencies } \\
\text { - Provide access to training and quality management } \\
\text { capabilities to support companies developing new products } \\
\text { - Provide training and information on process improvement } \\
\text { techniques from other industries } \\
\text { - Provide support to study inverter field performance to } \\
\text { provide better information on causes of inverter failure } \\
\text { - Studies on HALT and HASS testing methods for inverters }\end{array}$ \\
\hline $\begin{array}{l}\text { Technology/ } \\
\text { Design }\end{array}$ & $\begin{array}{l}\text { - Development of advanced switching, capacitor and other } \\
\text { component technologies for PV and DER inverters } \\
\text { - Modeling tools for experimentation with alternative } \\
\text { topologies, thermal management techniques, and new designs } \\
\text { - Support design of alternative inverter topologies to simplify } \\
\text { and reduce cost of inverters } \\
\text { - Modular designs would allow lower cost, interchangeable } \\
\text { components for multiple applications }\end{array}$ & $\begin{array}{l}\text { - Government can provide private-public R\&D funding to } \\
\text { support the development of new inverter technology to } \\
\text { support DG needs more broadly } \\
\text { - Funding assistance to study alternative inverter topologies } \\
\text { that significantly lower cost, and improve reliability or } \\
\text { efficiency } \\
\text { - Provide support for inverter modeling capabilities to support } \\
\text { design work (e.g. thermal management, etc...) }\end{array}$ \\
\hline Regulatory & $\begin{array}{l}\text { - Develop appropriate standards across the industry } \\
\text { - Harmonization of regulatory requirements } \\
\text { - Simplification and standardization of interconnection } \\
\text { requirements } \\
\text { - Studies and assessments of options for ungrounded designs, } \\
\text { safety issues, and a broader understanding of the implications }\end{array}$ & $\begin{array}{l}\text { - Assist the industry by providing detailed information on } \\
\text { regulatory requirements and variations across the U.S. } \\
\text { - Support studies that identify relationships between } \\
\text { regulatory requirements and design implications } \\
\text { - Support studies and analysis of safety issues, and pros and } \\
\text { cons of ungrounded systems }\end{array}$ \\
\hline Policy & $\begin{array}{l}\text { - Long-term programs for national incentives for PV. } \\
\text { - Policy that supports the PV industry broadly, which will also } \\
\text { support the inverter industry }\end{array}$ & $\begin{array}{l}\text { - Conduct analysis of alternative policy approaches to gain a } \\
\text { better understanding of the impact of program design on } \\
\text { market growth }\end{array}$ \\
\hline
\end{tabular}




\section{Suggested Role for Government Inverter Testing}

\section{Inverter testing at Sandia National Laboratories helps manufacturers experiment with innovative designs and improve their product.}

\section{Inverter Testing}

- Benchmarking tests to evaluate inverters against manufacturer specifications. Manufacturers generally agree that a comprehensive program of inverter testing and performance reporting would be very valuable to the industry.

- Development testing protocols to assist manufacturers in testing new inverter models.

- Utility compatibility and islanding tests. This type of testing provides manufacturers with information on their inverters' ability to meet UL 1741 requirements. Various utilities also request system-specific tests to be performed to understand the effect of PV inverters on their grid. Debate exists regarding the value of this, but it will remain a requirement.

- Temperature evaluations. These tests allow manufacturers to study temperature issues and test various strategies for thermal management, which are critical for product reliability.

Verification, validation, and characterization is extremely valuable to inverter manufacturers, who often do not have extensive in-house testing capabilities. Sandia should be provided with the resources necessary to support development of inverters for the U.S. market. 


\section{Suggested Role for Government Failure Documentation}

\section{Government can assist manufacturers in improving product reliability by studying and documenting failure of inverters in the field.}

\section{Documentation of Inverter Failures}

- Data of failure of inverters in the field is lacking. Most inverter manufacturers generally know the number of shipped units that were returned by customers, and little more. They generally do not look into what caused the inverter to fail.

- Larger companies are apparently capturing and documenting information on inverter field problems, but information is considered confidential.

- A comprehensive database of inverter failures would enable manufacturers to understand areas of weakness in designs and take corrective measures.

A possible role for government would be to conduct an extensive study of PV installations to document inverter failures and provide the results to manufacturers. 


\section{Documentation of information on key inverter components would assist manufacturers with design choices.}

\section{Component documentation}

- Inverter manufacturers have commented there are substantial differences in the performance of components (e.g. capacitors) available from different suppliers.

- Inconsistent specification, data sheets, and testing results exist on some of the key components for inverters (e.g. capacitors, fans, electrical connectors, power semiconductors, etc...) making it difficult for manufacturers to make proper comparisons of options.

A comprehensive study of inverter components would help manufacturers identify the best available products.

However, because components used in inverters are also used in many other applications, it is likely this type of work should be conducted as crosscutting research to support DG inverters and power electronics. 


\section{Suggested Role for Government Modeling Tools}

\section{Manufacturers need modeling tools to help with product development, but do not have the resources to develop them.}

\section{Modeling Tools}

- Manufacturers lack the resources to develop modeling tools for inverters. Such tools would enhance manufacturers' ability to explore options and select the optimal design.

- Sandia has the expertise to develop inverter models, and this type of work has been done in the past. However, one Sandia expert has commented that modeling of inverters was very difficult. But while completely accurate models may be nearly impossible to achieve, simplified models could still be useful.

While modeling tools would help manufacturers develop their products, developing such models is challenging. Therefore, resource requirements and the limitations in achievable results with this type of work needs to be examined before making extensive investments in new modeling tools. 


\section{Suggested Role for Government HALT and HASS}

\section{Manufacturers would benefit from understanding the costs and benefits associated with HALT and HASS testing.}

\section{HALT and HASS Testing Methods}

- Highly Accelerated Life Testing (HALT). This type of test subjects the inverter to extreme operating conditions in order to identify weak points in reliability for new designs. Some of the larger manufacturers conduct this testing, but most do not have resources or an understanding of proper testing procedures to follow.

- Highly Accelerated Stress Screening (HASS). Production testing to screen products knowing the operating and destruct limits based on HALT testing. Few manufacturers understand how to perform this testing, and its value for PV inverters is not understood by most.

Information and guidance regarding the value and applicability of HALT and HASS testing for inverters would benefit the industry. The trade-offs on cost, reliability, and life improvement need to be more fully understood.

A possible role for government would be to provide assistance to manufacturers in setting up HALT and HASS programs, as well as general guidelines to follow. 


\section{Suggested Role for Government Public-Private R\&D Partnership}

\section{The success of HRII indicates that government should consider funding another similar initiative.}

\section{Public-Private R\&D Partnership}

- The High Reliability Inverter Initiative (HRII), launched in 2002, will come to an end this year. The contractors selected (GE, Satcon, Xantrex) are developing prototypes of advanced inverters. At least one manufacturer has commented that their involvement in HRII has significantly impacted product development, by allowing them to explore options that would otherwise have been left aside.

- It should be noted that Sandia received many responses to their RFQ, six of which were deemed excellent. But only three manufacturers could be selected due to funding limitations $(\sim \$ 5 \mathrm{M})$.

- Programs such as this may be appropriate for development of advanced components such as switches, capacitors, and connectors that would benefit the broader DER inverter industry.

A formal review of the HRII program should be completed and shared with the industry to allow others to understand some of the key findings.

At this point, the results of HRII appear promising. Pending an evaluation of final results and appraisal of HRII success, another similar initiative may be a good use of DOE funds.

Use of similar approaches for DER inverter components should be explored. 


\section{Innovative inverter topologies could be a source for additional cost reduction and reliability and performance improvement. A potential role for government may be to fund studies to understand potential benefits.}

\section{Alternative Inverter Topologies}

- Innovative control and inverter design topologies have the potential to be a source of cost reduction, improved thermal management, and improved reliability. Several manufacturers have noted that there could be many advantages to the exploration of alternative topologies.

- Alternative topologies could be used to standardize "sub components" that could be used across product lines or in power electronics for other DER products.

Government could consider funding studies on the potential benefits of alternative inverter topologies. Many benefits have been suggested, but there does not appear to be significant direct evidence of the specific gains that might be achieved.

Research could focus on experimental topologies, with the objective of advancing the industry. 


\section{Suggested Role for Government Ungrounded Arrays}

\section{Government should consider conducting an assessment of performance, cost, and reliability benefits that could be derived from wider adoption of transformerless inverters.}

\section{Benefits and Issues Associated with Ungrounded Arrays}

- The 2005 National Electric Code allows the use of ungrounded arrays, but local electric code and utility interconnection in the United States still requires grounding. There are efficiency and cost benefits associated with eliminating transformers, but there is not acceptance of other protection schemes - and there are concerns about safety at local and utility levels. Local inspectors and regulators do not generally accept other protection schemes.

A sponsored study on the pros and cons of ungrounded arrays and elimination of transformers could be a general benefit to the DER industry. There is significant experience in Germany with tranformerless inverters and transferring this knowledge to the United States would be valuable to the industry.

Note:

Magnetek announced on January 9, 2006, that its transformerless Aurora inverters have been listed by CEC. (source: Business Wire)

If the Aurora inverters are adopted by some PV system designers/installers, this could be an important first step in allowing transformerless inverters to enter the U.S. market. 


\section{Suggested Role for Government Standards}

\section{Standards are a major complaint of manufacturers, but possible roles for DOE in this area may be limited.}

\section{Standards}

- Grid connection: Manufacturers repeatedly ask for standards to be harmonized, for ungrounded PV arrays and transformerless inverters to be accepted, and for relaxation of installation requirements that retain safety.

- Communication: Standards for communicating PV system information are needed for data monitoring and for utility interaction. Without a single, universal standard, manufacturers will develop proprietary standards that will lead to fragmentation and hamper growth of this technology.

- Performance metrics: Sandia and Endecon Engineering (now BEW) are currently developing the PV Inverter Performance Test Procedure. Manufacturers have been asking for this type of standard, and support for this activity should continue.

Grid connection and installation: These standards are the domain of organizations like UL (UL 1741), IEEE (IEEE 1547), and NFPA (NEC 2005). However, DOE may be able to influence these organizations or provide leadership to help bring about the changes that inverter manufacturers are asking for. In addition, the following specific recommendations have been made relative to UL 1741:

1. Subsidize the cost of acquiring the UL 1741 standard.

2. Subsidize the cost of attending UL 1741 meetings to encourage industry participation.

Communication: EPRI is leading the effort to develop a communication standard for DER. DOE should support this initiative.

Performance metrics: Sandia and Endecon Engineering are currently developing the PV Inverter Performance Test Protocol. Manufacturers have been asking for this type of standard, and support for this activity should continue. 


\section{Suggested Role for Government Policy Assessment}

\section{Understanding the role of incentive programs and policies for PV will be critical to the long-term growth necessary to meet cost, performance, and reliability goals.}

\section{The Impact of Alternative Policies and Incentives for PV}

- Increasing market volume is one of the major drivers in achieving cost and performance goals for inverters. Market volume in the United States is growing, but not to the degree it has in Germany and Japan.

- There is significant fragmentation in policies to promote the adoption of PV. California, New Jersey, and New York lead the country with programs to buy-down the price of new systems. National policy provides investment tax incentives. European feed-in tariffs have developed a much more rapidly growing market and are driving most of the investment in the industry.

- An assessment of impact of alternative policies would benefit the industry.

Government could fund a study of the impact of PV policy programs with the objective of understanding the relationship of program design to market growth, as well as options for making U.S. policies more effective. Understanding the interaction of federal, state, and municipal programs will be increasingly important to further industry growth. 


\section{References}

1. Photon International, Invasion of the inverters, April 2004.

2. Photon International, Market Survey of Inverters, April 2005.

3. Renewable Energy World, Choosing the right inverter, March-April 2004.

4. Photovoltaics, Looking to Spain, September-October 2004.

5. R.West et al., Status and Needs of Power Electronics for Photovoltaic Inverters: Summary Document, Sandia Report SAND2002-1085, May 2002.

6. Dan Ton, Ward Bower, Summary Report on the DOE High-tech Inverter Workshop, January 2005.

7. Dan Ton, Ward Bower, Summary Report on the DOE Workshop On a Systems-driven Approach to Inverter Research and Development, September 2003.

8. Gonzalez et al., PV Inverter Testing, Modeling, and New Initiatives, NCPV and Solar Program Review Meeting 2003, NREL/CD-520-33586.

9. Bonn, Russell H., Developing a "Next Generation" PV Inverter, IEEE 2002.

10. Sarjeant et al., Capacitive Components for Power Electronics, IEEE 2001.

11. IEA, Grid-connected photovoltaic power systems: Survey of inverter and related protection equipments, PVPS Task V Report IEA-PVPS T5-05: 2002, December 2002.

12. Jan Schaeffer et al, Learning from the Sun, Final report of the Photex project, August 2004.

13. Jan Schaeffer et al, Photovoltaic Experiences, Synthesis report of the Photex-project, June 2004.

14. Solar Electric Power Association, Residential PV Systems Cost Report, December 2001.

15. Solar Electric Power Association, Large Systems Cost Report - 2001 Update, September 2001.

16. Photon International, PV industry in high spirits at Intersolar, August 2005 


\section{References}

\section{Conference Interviews June 6-9, Barcelona, Spain}

1. Mitsubishi

2. SMA

3. Fronius

4. Outback

5. GE

6. Xantrex

7. Sustainable Energy Technologies

8. Heliotronics

9. SunPower

10. Siemens

11. PowerLight

12. SolarMax 


\section{NCI Contacts}

Lisa Frantzis | Director

Lfrantzis@navigantconsulting.com

781-270-8314 direct

Etienne Parent | Consultant

eparent@navigantconsulting.com

781-270-8428 direct

Paula Mints | Associate Director pmints@navigantconsulting.com 415-356-7174 direct

David Walls | Director

dwalls@navigantconsulting.com

781-270-8436 direct

Shannon Graham I Managing Consultant sgraham@navigantconsulting.com

415-399-2164 direct 


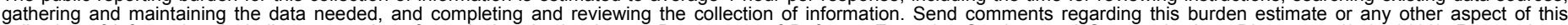

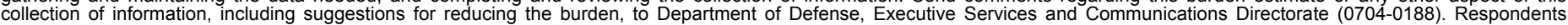

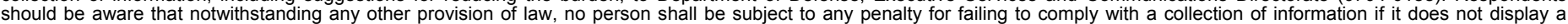
currently valid OMB control number.

PLEASE DO NOT RETURN YOUR FORM TO THE ABOVE ORGANIZATION.

\begin{tabular}{|c|c|c|}
\hline $\begin{array}{l}\text { 1. REPORT DATE (DD-MM-YYYY) } \\
\text { January } 2006\end{array}$ & $\begin{array}{ll}\text { 2. } & \text { REPORT TYPE } \\
& \text { Subcontractor Report }\end{array}$ & 3. DATES COVERED (From - To) \\
\hline \multirow{3}{*}{\multicolumn{2}{|c|}{$\begin{array}{l}\text { 4. TITLE AND SUBTITLE } \\
\text { A Review of PV Inverter Technology Cost and Performance } \\
\text { Projections }\end{array}$}} & $\begin{array}{l}\text { 5a. CONTRACT NUMBER } \\
\text { DE-AC36-99-GO10337 }\end{array}$ \\
\hline & & 5b. GRANT NUMBER \\
\hline & & 5c. PROGRAM ELEMENT NUMBER \\
\hline \multirow{3}{*}{\multicolumn{2}{|c|}{$\begin{array}{l}\text { 6. } \text { AUTHOR(S) } \\
\text { Navigant Consulting Inc. }\end{array}$}} & $\begin{array}{l}\text { 5d. PROJECT NUMBER } \\
\text { NREL/SR-620-38771 }\end{array}$ \\
\hline & & $\begin{array}{l}\text { 5e. TASK NUMBER } \\
\text { PVC6.1501 }\end{array}$ \\
\hline & & 5f. WORK UNIT NUMBER \\
\hline $\begin{array}{l}\text { 7. PERFORMING ORGANIZATION } \\
\text { Navigant Consulting Inc. } \\
77 \text { South Bedford St. } \\
\text { Burlington, MA } 01803\end{array}$ & ME(S) AND ADDRESS(ES) & $\begin{array}{l}\text { 8. PERFORMING ORGANIZATION } \\
\text { REPORT NUMBER } \\
\text { KACX-4-44451-04 }\end{array}$ \\
\hline \multirow{2}{*}{\multicolumn{2}{|c|}{$\begin{array}{l}\text { 9. SPONSORING/MONITORING AGENCY NAME(S) AND ADDRESS(ES) } \\
\text { National Renewable Energy Laboratory } \\
1617 \text { Cole Blvd. } \\
\text { Golden, CO } 80401-3393\end{array}$}} & $\begin{array}{l}\text { 10. SPONSOR/MONITOR'S ACRONYM(S) } \\
\text { NREL }\end{array}$ \\
\hline & & $\begin{array}{l}\text { 11. SPONSORING/MONITORING } \\
\text { AGENCY REPORT NUMBER } \\
\text { NREL/SR-620-38771 }\end{array}$ \\
\hline
\end{tabular}

12. DISTRIBUTION AVAILABILITY STATEMENT

National Technical Information Service

U.S. Department of Commerce

5285 Port Royal Road

Springfield, VA 22161

13. SUPPLEMENTARY NOTES

NREL Technical Monitor: Robert Margolis

14. ABSTRACT (Maximum 200 Words)

The National Renewable Energy Laboratory (NREL) has a major responsibility in the implementation of the U.S. Department of Energy's (DOE's) Solar Energy Technologies Program. Sandia National Laboratories (SNL) has a major role in supporting inverter development, characterization, standards, certifications, and verifications. The Solar Energy Technologies Program recently published a Multiyear Technical Plan, which establishes a goal of reducing the Levelized Energy Cost (LEC) for photovoltaic (PV) systems to $\$ 0.06 / \mathrm{kWh}$ by 2020 . The Multiyear Technical Plan estimates that, in order to meet the PV system goal, PV inverter prices will need to decline to $\$ 0.25-0.30 \mathrm{Wp}$ by 2020. DOE determined the need to conduct a rigorous review of the PV Program's technical and economic targets, including the target set for PV inverters. NREL requested that Navigant Consulting Inc. $(\mathrm{NCl})$ conduct a review of historical and projected cost and performance improvements for PV inverters, including identification of critical barriers identified and the approaches government might use to address them.

\section{SUBJECT TERMS}

NREL; Navigant Consulting Inc.; NCl; Solar Energy Technologeis Program; solar; PV; photovoltaics; PV inverters; Sandia National Laboratories; SNL; multiyear technical plan; European market; learning rate; U.S. manufacturers; inverter topologies; Highly Accelerated Life Testing; HALT; Highly Accelerated Stress Screening; HASS; High Reliability Inverter Initiative; HRII

\begin{tabular}{|c|c|c|c|c|}
\hline \multicolumn{3}{|c|}{ 16. SECURITY CLASSIFICATION OF: } & \multirow{2}{*}{$\begin{array}{l}\text { 17. LIMITATION } \\
\text { OF ABSTRACT } \\
\text { UL }\end{array}$} & \multirow{2}{*}{$\begin{array}{l}\text { 18. NUMBER } \\
\text { OF PAGES }\end{array}$} \\
\hline $\begin{array}{l}\text { a. REPORT } \\
\text { Unclassified }\end{array}$ & $\begin{array}{l}\text { b. ABSTRACT } \\
\text { Unclassified }\end{array}$ & $\begin{array}{l}\text { c. THIS PAGE } \\
\text { Unclassified }\end{array}$ & & \\
\hline
\end{tabular}

19a. NAME OF RESPONSIBLE PERSON

19b. TELEPHONE NUMBER (Include area code) 